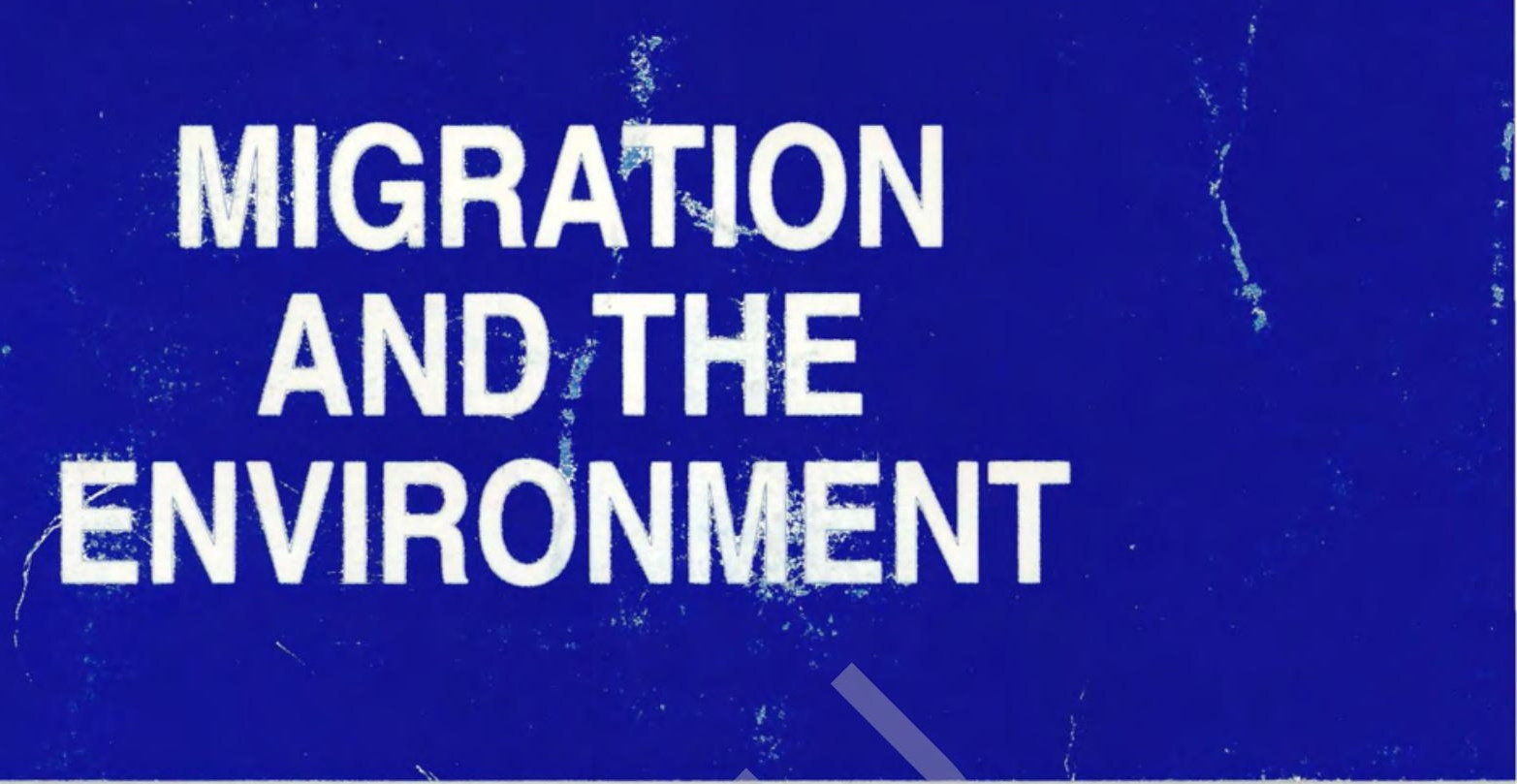

JUNE 1992

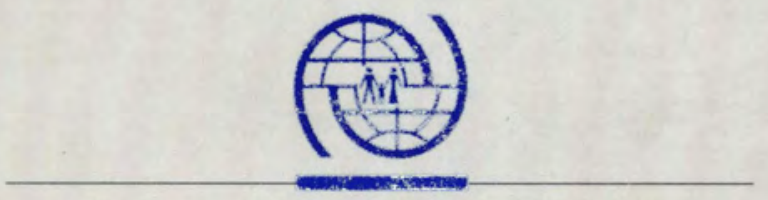

IOM International Organization for Migration

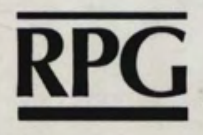

The Refugee Policy Group 


\section{MIGRATION AND THE ENVIRONMENT}

JUNE 1992
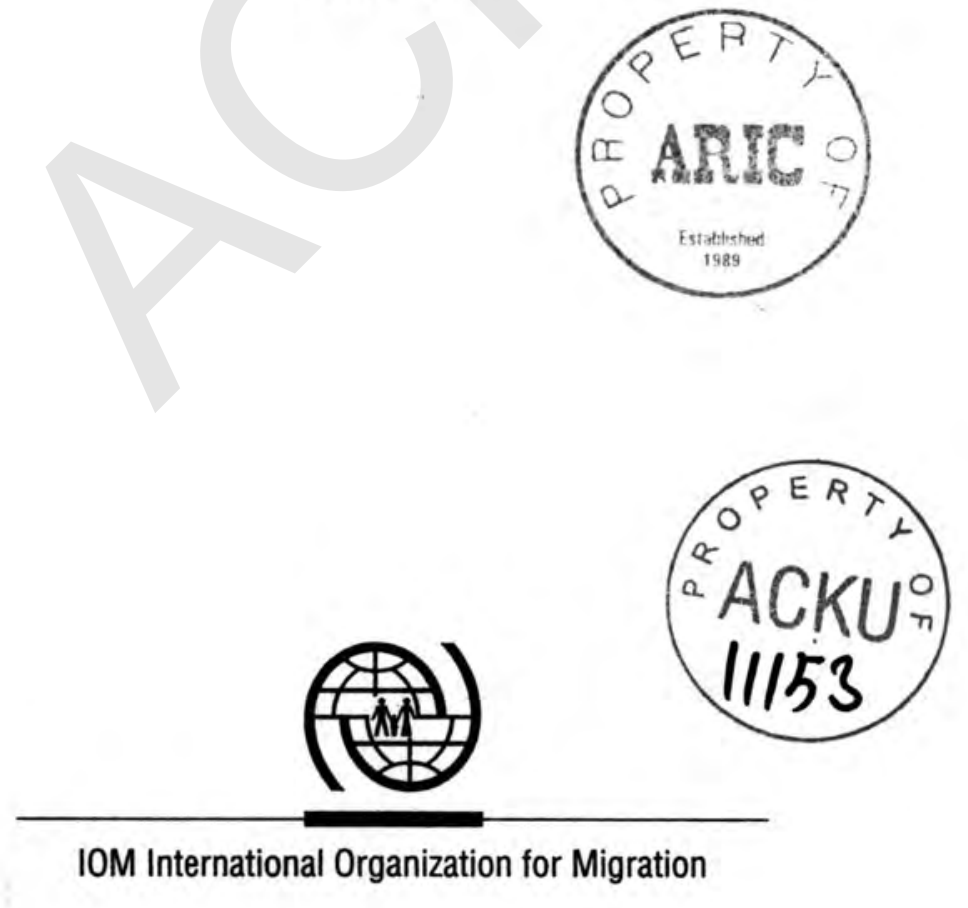

\section{$\overline{\mathrm{RPG}}$}

The Refugee Policy Group 


\section{FOREWORD}

Large numbers of people are moving as a result of environmental degradation that has increased dramatically in recent years. The number of such migrants could rise substantially as larger areas of the earth become uninhabitable as a result of climate change from global warming, rising sea levels, drought, floods and other geophysical effects. Large-scale migration can in turn affect the environment in the receiving countries.

Recognizing the potential migration ramifications of environmental degradation, the International Organization for Migration and the Refugee Policy Group embarked on a yearlong cooperative effort to improve understanding of the interconnections between the environment and migration. Through the joint project, we have aimed to foster cooperation between institutions in the migration and environment fields, provide a forum to discuss policy and program issues related to environmental migration, and frame an agenda for future action.

Two major products came out of this work: a background paper setting out the range of issues to be addressed and an international conference, sponsored in cooperation with the Swiss Foreign Ministry, that brought together environment and migration specialists and officials of governments, intergovernmental organizations, and non-governmental organizations. Participants came from Australia, Bangladesh, Canada, Egypt, Germany, India, Malaysia, Norway, the Philippines, Senegal, Switzerland, the United Kingdom, and the United States. Section One of this publication presents the background paper and Section Two includes the summary of the conference.

Development of more comprehensive strategies requires better understanding of the factors underlying environmental degradation and the determination to move: political, security and human rights situations; economic factors; demographics; and the obstacles and opportunities for migration. The project has underscored the need for new approaches at the international, regional and national levels to address underdevelopment and overpopulation imbalances as necessary preconditions for reducing environmental degradation and migration pressures. Neither environmental damage nor migration is a matter of purely sovereign interest (since they each often affect other countries) and cannot, therefore, be left to unilateral action.

Given the degree of the environmental damage already observed, some large scale movements may be inevitable. The international system responsible for migration is illprepared for these phenomena. Many of the people who are forced from their homes because of extreme poverty, environmental degradation and similar causes seem to fall through the cracks of the current arrangements. While concern has been expressed about movements from the developing countries towards the developed world as the planet becomes more 
crowded and polluted, experience shows that most such movements affect developing countries themselves. They are the least likely to have the resources to cope.

One particular concern linking migration and environmental conditions related to countries which will be receiving back large numbers of their own nationals, who had fled conflicts that are now being resolved. Afghanistan, Cambodia, Ethiopia and El Salvador have suffered devastating environmental effects of war. In some cases large areas have become uninhabitable. International efforts are needed to help these war-torn nations to recover and rehabilitate damaged lands.

The world's leaders met at the Earth Summit in Rio de Janeiro to adopt a charter to reduce global environmental problems and promote sustainable development. Their actions are the beginning of a process that, we all hope, will lead to a more habitable and productive world. Should the process fail, the humanitarian consequences will be immense.

My personal appreciation goes to the Refugee Policy Group for its work in cooperating with IOM to bring these issues to international attention. The background paper and conference summary present an agenda for action that IOM will be seriously considering in the months ahead. It is our hope that others will find it as useful a document in framing issues and options for the future.

James N. Purcell, Jr.

Director General

International Organization for Migration 


\section{CONTENTS}

FOREWORD

BACKGROUND PAPER

Acknowledgements $\quad 7$

Introduction $\quad 8$

Purpose and Scope of the Paper 10

A Framework for Understanding the Relationship between the Environment and Migration 11

Policy and Program Issues $\quad 22$

Conclusion $\quad 29$

References $\quad 31$

$\begin{array}{ll}\text { CONFERENCE REPORT } & 37\end{array}$

Acknowledgements $\quad 39$

List of Attendees $\quad 54$ 


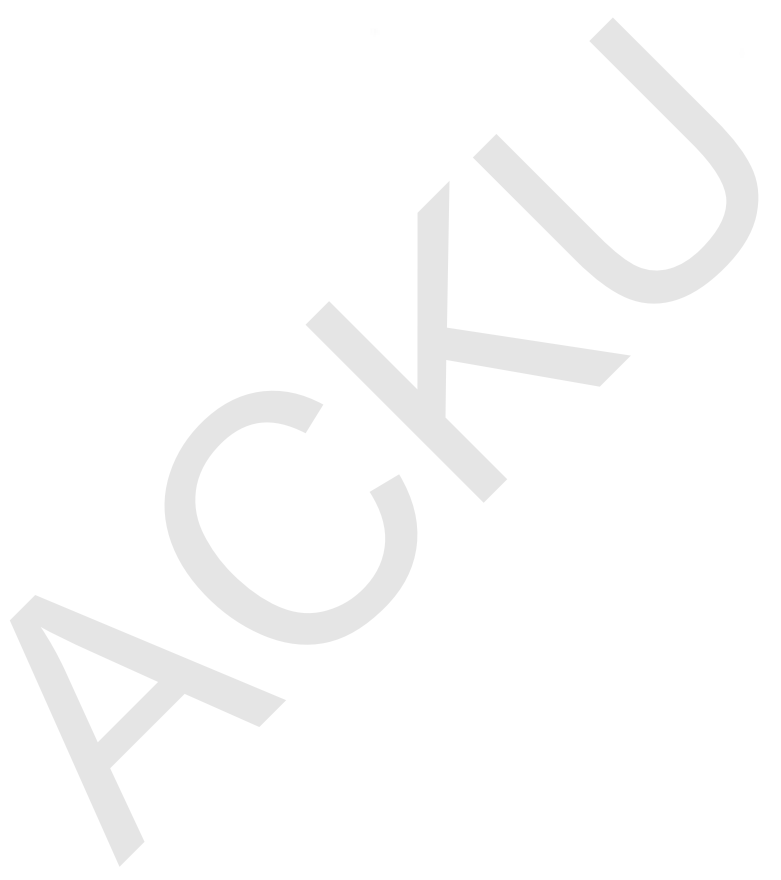


SECTION ONE

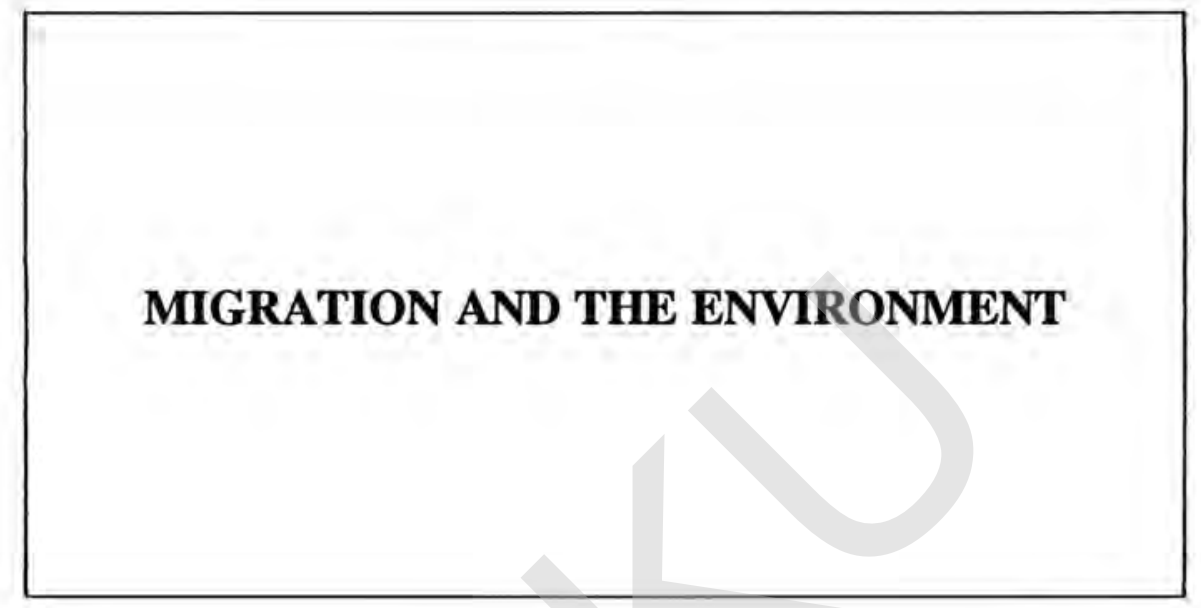

BACKGROUND PAPER

The International Organization for Migration The Refugee Policy Group

June 1992 


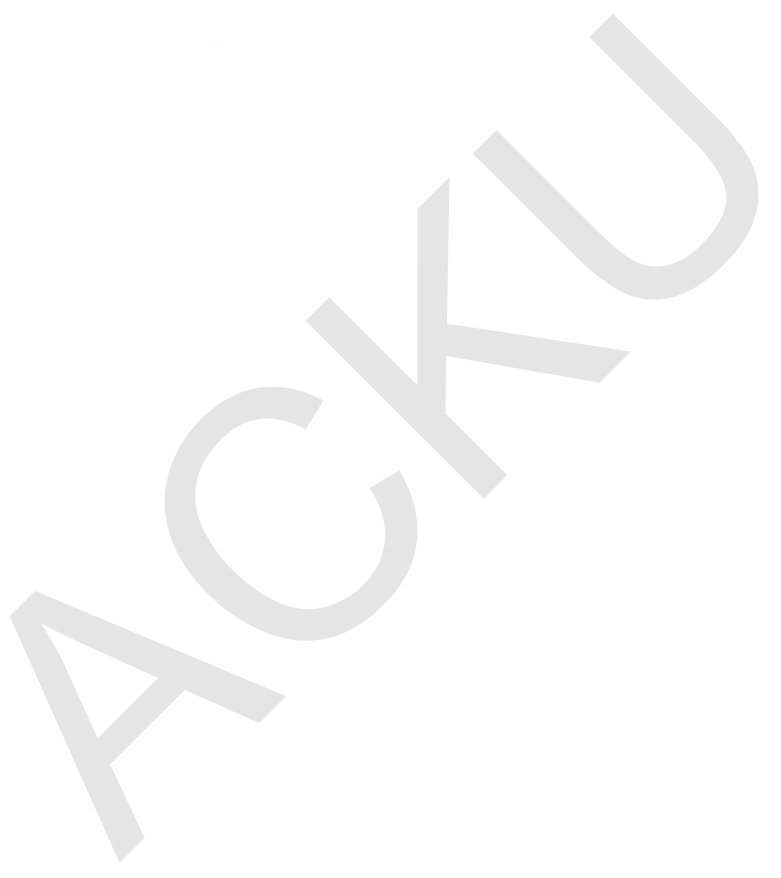




\section{ACKNOWLEDGEMENTS}

This paper is the result of a policy research project jointly funded by the International Organization for Migration (IOM) and the Refugee Policy Group (RPG). Dennis Gallagher was the Project Director and Susan Forbes Martin the Principal Investigator, both of RPG. Peter Schatzer and Reinhard Lohrmann of IOM made key contributions to the project. While a variety of people offered information and perspectives during the project, particular thanks are expressed to David Barker, Tom Fox, Ben Barber and Jesse Bunch. RPG worked closely with the Universities Field Staff International and the Natural Heritage Institute, whose case studies on environmental migration in India, Brazil, Haiti and the Horn of Africa provided valuable information that has been incorporated into this report. 


\section{INTRODUCTION}

Environmental and migration issues have prominent roles in national and international policy and program agendas. The earth is becoming less habitable due to factors such as global warming, deterioration of agricultural lands, desertification, salinization, water pollution, and natural and human-made disasters. Growing environmental degradation holds the potential for creating sizeable population displacements that the world community is illequipped to prevent or respond to in an effective manner. In turn, migration itself becomes a factor in environmental degradation, particularly when movements are massive, rapid and unplanned.

There has always been a close relationship between migration and the environment. Whether caused by nature, civil conflict, war, persecution, over-population--or a combination of these factors--some people have found it necessary to flee from their homes temporarily or permanently for the immediate reason that the land on which they live can no longer sustain them. Some of these movements are transnational; others occur within a country. Some are due primarily to environmental factors, while others are more complex and involve a combination of immediate and long-term issues including economic dislocations, social tensions, armed conflict, human rights violations, the pressures of economic development, population growth, and political persecution.

To a large extent the environment field is ahead of the migration field in examining the interconnections between environmental degradation and population displacement. Two seminal reports, one issued in 1985 by the United Nations Environmental Program (UNEP) and the second in 1988 by WorldWatch, brought public attention to the issue of migration caused by environmental problems.

The UNEP report, prepared by Essam El-Hinnawi, coined the phrase "environmental refugees" as:

"those people who have been forced to leave their traditional habitat, temporarily or permanently, because of a marked environmental disruption (natural and/or triggered by people) that jeopardized their existence and/or seriously affected the quality of their life." 1

Environmental disruption refers to "any physical, chemical and/or biological changes in the ecosystem (or the resource base) that render it, temporarily or permanently, unsuitable to support human life." 2

1 Essam El-Hinnawi, Environmental Refugees (Nairobi: United Nations Environmental Program, 1985), p. 4.

2 Ibid. 
El-Hinnawi described three broad categories of individuals who would fit this definition of environmental refugee: those who have been temporarily displaced because of an environmental stress, such as earthquakes or cyclones, and who will be able to return to their habitat; those who have been permanently displaced because of permanent changes to their habitat, such as the establishment of dams and associated man-made lakes; and those who migrate temporarily or permanently in search of a better life because their original habitat can no longer meet their basic needs.

The definition of "environmental refugee" provided in the UNEP report encompasses millions of individuals. A Worldwatch report, using similar definitions, estimated that about 10 million people could be considered "environmental refugees" in $1988 .{ }^{3}$ Extrapolating from the numbers of past environmental displacements and likely future disruptions indicates that by the turn of the century as many as one billion people may be displaced from their homes because their basic means of survival will have been destroyed.

The numbers are of course alarming. In fact, they are so large and include so many different types of migrants - some classic refugees, others victims of natural disasters or economic development projects --that it is difficult to use them in developing policies and programs for addressing displacements arising from environmental disruption. This is perhaps not surprising. As stated, it is primarily environmentalists who have examined the relationship between the environment and migration. The alarmingly high numbers of possible migrants cited have been used primarily to promote better environmental policies. Less attention has been given to the adequacy of migration policies, programs and institutional relationships for handling the various types of movements that are already resulting from environmental degradation.

Much of the research to date on environmental migration has focused on the root causes of these population movements. Certainly, an understanding of these causes is a first step in understanding the overall phenomenon. To fully address the issue of environmental migration, however, we must go beyond a discussion of causes and look towards realistic solutions. Solutions are needed not only for the underlying reasons for the movement but also for the current and future situation and needs of the migrants and the places to which they relocate. Also needed is more precise knowledge and understanding of the specific types of movements that result from different causes, the specific needs of the affected populations (for example, material help, legal protection, etc.), the level and duration of assistance and/or protection required, the prospects for individuals returning to their homes or resettling in other locations, and other similar issues.

3 Jodi Jacobson, Environmental Refugees: A Yardstick of Habitability (Washington: Worldwatch, 1988). 


\section{PURPOSE AND SCOPE OF THE PAPER}

The purpose of this paper is to survey and synthesize available literature and expert opinion on the relationship between the environment and migration. It is a background paper to clarify concepts and definitions for policy consideration.

The paper will present available data on environmentally-driven migration, develop a typology of the kinds of migration that result from environmental factors, and examine how environmental factors interact with political and economic causes of migration. It will also analyze the legal mandates of various governmental, intergovernmental, and nongovernmental organizations and their roles and relationships with a view toward understanding their role within the context of various types of environmental migration. Additionally, it will describe current policies and projects which seek to avert or better cope with emergency migration due to environmental factors; frame key policy issues; and make recommendations as to steps that can be taken to address them. 


\section{A FRAMEWORK FOR UNDERSTANDING THE RELATIONSHIP BETWEEN THE ENVIRONMENT AND MIGRATION}

Understanding the relationship between the environment and migration requires an assessment of the various factors that influence the types of movements, the needs of the migrants and receiving communities, and the potential responses and solutions to these movements. The model used in this paper first assesses the environmental causes of migration. Further determining the scale and nature of the migrations are a variety of intervening factors, such as the political situation in the affected country. Depending on the environmental cause and the intervening factors, the migrations will vary: they may be temporary or permanent; large-scale or small-scale; emergency or continuing; internal or transnational; etc. These factors will in turn determine the specific needs of the migrants which could include: emergency assistance, longer-term care and maintenance, legal and/or physical protection, assistance in relocating, assistance in returning to their homes, etc. They will determine as well what local impacts are likely to be felt by the areas to which the migrants move.

Each of these elements of the model is discussed below.

\section{Causes of Environmental Migration}

Environmental disruptions can be classified in several ways, but six categories highlight the most important causes and dynamics of environmental migration. These are: elemental disruptions, biological disruptions, slow-onset disruptions, accidental disruptions, disruptions caused by development, and environmental warfare. Each category covers a spectrum of disruptions ranging from mild to catastrophic. Environmental migrants are but one class of victims that emerge from the most severe disruptions.

Elemental disruptions include cyclones, volcanoes, earthquakes and other "natural" disasters. They have a rapid onset and are prompted by climactic or geological forces. Their destructiveness depends more on the number of vulnerable people in the affected area than on their inherent severity. The number of people affected by natural disasters has accelerated in each decade since the 1960 's. During the 1960 's, 28 million people were affected by such

disasters while 64 million were affected during the 1980 's. 4 Poor people in developing countries are the most severely affected by natural disasters.

4 UN Development Programme, Central Evaluation office, "UNDP/UNDRO Co-Operation: An Evaluation," December 1989, p. 19. 
Elemental disruptions are not a major cause of migration, though the poorest and most vulnerable segments of society may be propelled into destitution, and individuals may be prompted to migrate temporarily to cities.

Earthquakes, storms and floods inflict severe environmental economic damage where they strike, but they rarely degrade the ecosystem to the point that it cannot sustain human life. One of the worst natural disasters in recent years was the flooding in Bangladesh in August-September 1988, which affected 48 million people, destroyed at least one million houses, and brought the economy to a standstill for the following six months. Bangladesh was struck in a similar way in 1991.

Biological disruptions include those initiated by pathogens, insects, pests, and flora. The historical role of biological disruptions in making environmental refugees has been greatly diminished by modern pesticides, insecticides, and pharmaceuticals. Locusts are possibly the most serious biological threat in the 1990 's, but the damage caused by locusts can be assessed only against the background of broad ecological deterioration throughout the locust range, from the Western Sahel to east-central Africa. In the past, biological disasters have caused major population movements, particularly where they affect production of a staple food item.

Slow-onset disruptions have complex root causes in which ecological and human activities interact over extended periods, leaving large numbers of people vulnerable. Global warming, deforestation, land degradation, erosion, salinity, siltation, waterlogging, and desertification are among the most prominent geophysical processes in the category of environmental disruptions. They contribute to drought, which is the major meteorological component, and to famine, which is the most important result of severe disruption of the ecosystem for human and animal populations. Since the causal factors are mutually interdependent, they create feedback which accelerates the process and reduces the capacity of ecosystems to regenerate themselves.

Forests are being lost at the rate of more than 11 million hectares annually, with the largest decline in the humid tropics. Deforestation is severe in many parts of Nepal, nearly all of Bangladesh and Afghanistan, and large scattered areas of India and Malaysia. The Sahelian belt from Sudan to Mauritania has been almost entirely stripped of trees by the combined forces of drought, overgrazing and fuel-stimulated tree cutting. The forests of Haiti have also been almost entirely cut, and forests in Central America and parts of South America are far below levels required for sustainable development.

A number of countries have instituted planned resettlement schemes, some of which have actually contributed to deforestation. Indonesia, for example, has run a transmigration programme since 1969 which has resettled about 500,000 families on land that had previously been largely virgin, tropical forest. The land is now suffering from soil compaction, erosion and lowering of available soil nutrient content. 5

5 Independent Commission on International Humanitarian Issues, The Vanishing Forest: The Human Consequences of Deforestation (Zed Books, Ltd., London, 1986), p. 32. 
Irrigation is contributing to salinity and waterlogging that is affecting 200,000 to 300,000 hectares of the world's best land each year. Historically, irrigation has probably been the first human impact on the environment which rendered it uninhabitable, although in certain cases it has rendered areas habitable.

Desertification is the diminution or destruction of the biological potential of the land, which leads ultimately to desert-like conditions and is an aspect of the widespread deterioration of ecosystems under the combined pressure of an adverse and fluctuating climate and excessive exploitation. Roughly 50 percent of the people most directly affected by desertification live in the Sahel. Other parts of the world threatened by desertification are the Andean areas of South America as well as Brazil, Mexico, and parts of Western Asia and the Indian subcontinent. In 1984, UNEP estimated that 4,000 million hectares of rangelands, rain-fed croplands and irrigated lands are affected by desertification.

Often desertification is accompanied by other factors which also precipitate movement. In Northeast Brazil, for example, many people left their homes due to drought combined with other factors such as population increase, poverty, lack of opportunity, soil deterioration, inequitable land distribution, modernization, and poor government policies, according to a recent study. 6 The interior of the region is a semi-arid zone where drought is common. Irregular rainfall is the cause of drought which makes planting and growing of crops difficult. This natural phenomenon is compounded by the relative poverty and high fertility rates of the inhabitants who do not have reserves to rely upon when drought causes insufficent food production. Government policies encouraged urbanization and outmigration from the northeast. They also encouraged large-scale commercial agricultural enterprises. As a result, large landowners bought land for cattle ranching. They tend to displace sharecroppers during drought periods in order to have sufficient water for the animals.

The problems seen to date may accelerate in the years ahead. There is now strong evidence of an increase in global atmospheric temperature by .05 to .07 degrees Celsius since 1860 due to increases of about 25 percent in carbon dioxide and other greenhouse gases. Steady or accelerated increases of this magnitude will severely alter climate, forests, and agriculture in the next century. Climactic changes pose problems because they will be continuous, irreversible, and open-ended. One of the many critical effects will be a rise of the levels of the oceans of between $15 \mathrm{~cm}$ and $30 \mathrm{~cm}$ over the next four or five decades. Densely populated low-lying countries, and certain island states are most vulnerable. Egypt, Bangladesh, and the Maldives have received the most attention.

Accidental disruptions have become common and inevitable by-products of the industrial revolution. Accidents in the manufacture, transport, and application of chemicals have killed or injured thousands of people. Nuclear reactors have killed fewer people, but have caused far more severe environmental disruption and the movement of more than 100,000 persons because of damage to their immediate environment.

The most serious chemical accident was the release of a cloud of methylisocyanate from the Union Carbide plant in Bhopal, India, on 3 December 1984. More than 200,000 people

6 Thomas G. Sanders, "Northeast Brazilian Environmental Refugees: Part I, Why They Leave. " Field Staff reports, Natural Heritage Institute, 1990-91; No. 20. 
became ill, and about 2,500 were killed by the release. However, this and other chemical accidents did not require mass evacuation over a prolonged period.

Toxic waste dumps seem to have had more serious and durable environmental consequences for nearby residents than chemical plants. In the United States, toxins dumped at Love Canal, Centralia and a few Superfund sites have forced the permanent relocation of several thousand families.

The most serious nuclear power accident forced the evacuation of 135,000 people from a $750 \mathrm{sq}$. km area around Chernobyl, USSR. On 26 April 1986, a partial meltdown of Unit 4 was caused by six different operator errors. Radioactive material in the core was released into the environment. After a 36-hour delay, people in a $30 \mathrm{~km}$ zone around the power station were evacuated, of whom 18,000 reported to the hospital for checkups. A few days later, 60,000 children were evacuated from as far as $160 \mathrm{~km}$ north of Chernobyl.

Disruptions caused by development and urbanization are a further cause of migration. As with other categories of environmental disruptions, those caused by development cover a wide range. At one extreme is an individual's decision to seek a better life in a city, in which case environmental deterioration is just one of several factors. At the other extreme is government-enforced resettlement of everyone in a region, such as has occurred in Ethiopia.

Throughout the world, where rural economies are based on agriculture and natural resource exploitation, employment levels are dependent on a healthy environment. However, in developing countries sustainable development has seldom resulted from efforts to improve the economic situation of the population. Urban migration may be a sign that land degradation, whether caused by poverty or industry, has reached a critical point. The most vulnerable are the poorest and most marginal people, particularly indigenous peoples. They typically have simpler technologies and social organizations than members of the mainstream national society, and are poorly able to defend their territories from encroachment and "development."

Lakes that form upstream from big dams have forced the resettlement of a significant number of people, who form a special class of persons affected by environmental change. There are 113 dams over 150 meters high, most of them in Africa, Asia and Latin America. Most indigenous people do not benefit in any way from big dam projects, whose hidden costs include forced relocation. 7

In India, it is estimated that some 20 million people have been displaced by official projects including dams, mines, forest preserves and irrigation. 8 Irrigation projects alone have displaced about 6.5 million people in India. Some of these migrants were directly displaced by the dam or other project; others moved as common land and water were reduced

\footnotetext{
7 Pete S. Michaels and Steven F. Napolitano, "The Hidden Costs of Hydroelectric Dams," Cultural Survival Quarterly, Vol. 12, No. 2 (1988), p. 3.

8 Clarence Maloney "Environmental and Project Displacement of Population in India, Part I: Development and Deracination," 1990-91/No. 14, Field Staff Reports. Maloney cites statistics by Lokayan, a Delhi-based office representing peoples' movements.
} 
as a result of these projects. These movements are particularly serious because there are no policies for reducing the impact of relocation. Land is not available for rehabilitation or compensation when people are displaced. The absence of relocation policies creates secondary migration, particularly to cities. Currently, no framework exists for negotiations between the government and the uprooted regarding ways to deal with the causes and consequences of this displacement. It is argued that the projects are in the public interest, but there is no way to measure whether in fact the degree of displacement caused by the projects is in the public interest.

The departure of significant numbers of able-bodied men to work on development projects may leave the rest of their family and village worse off than before, with inadequate manpower to farm effectively. For example, during the 1970 's farmers affected by the Aswan High Dam left their farms to work on the dam project and mined over 1 million hectares of their own productive soil to make bricks for the construction of the dam.

Environmental warfare describes the fact that the environment often becomes a major target in times of conflict. Environmental deterioration is both a cause and a result of armed conflict and persecution. It is no coincidence that the countries that feature prominently in any list of environmental refugees--Ethiopia, Sudan, Somalia, Chad, Afghanistan, Haiti, Honduras, and El Salvador--are those experiencing both ecological disasters and armed conflict. Two of many possible examples are the wars in Vietnam from 1965-73 and El Salvador from 1980-present. In both conflicts, massive quantities of herbicides have been used to remove ground cover that conceals guerrilla fighters. A 1982 UNEP report on Vietnam found that "chemical herbicides completely destroyed 15,000 sq kilometers of mangrove forest and caused damage to another 1,500 or so sq kilometers. The natural recovery of these areas is proceeding at a disturbingly slow rate and millions of people have been affected by this deliberate destruction of the environment." 9 El Salvador is a good example of a vicious circle of ecological deterioration and armed conflict stemming from historical conflicts over ownership and control of land. Particularly disturbing for the future is that "only now are we perhaps on the threshold of developing the more sophisticated technical ability to control atmospheric, tectonic and biotic factors of the environment for effective hostile military purposes," writes Arthur Westing. 10

\section{Intervening Factors}

The decision to move from one's own home is seldom a straightforward, simple one. While a specific event may precipitate the actual movement, a range of often complicated factors usually affects the final decision to become uprooted. People will often remain where they are trying to cope with the impacts of an environmental disruption until they are unable to do so any longer. The political and economic situation of their countries are factors that ultimately affect their capacity to remain in their homes. Other factors are obstacles to movement, including the unwillingness of the areas to which they could migrate to receive

9 El Hinnawi, p. 33

10 Arthur H. Westing, "Environmental Warfare, a Technical, Legal and Policy Appraisal," (Stockholm International Peace Research Institute, 1984), p. 1. 
them. Finally, the availability of international assistance is a factor that will influence whether people need to move and the places to which they migrate.

Political, security, and human rights factors determine the extent to which a government is willing and able to help its citizenry deal with environmental disruptions. As discussed above, environmental degradation has been a consequence of international and internal armed conflicts. Governments and resistance forces cause environmental damage through actions whose primary purpose is to subdue populations or inflict harm on perceived enemies. The parties causing the environmental disruptions may be utilizing these means in order to precipitate movements of people they believe are aiding the other side.

In other cases, ethnic and racial tensions affect the potential for people to cope with environmental damage. The victims of environmental disruptions, particularly slow-onset ones, are often nomads and indigenous people inhabiting fragile mountain or forest. ecosystems. Central governments may be hostile to these groups because of tribal, political or religious differences, or economic interests. In some cases, the tensions between groups affect decisions as to where a dam or other development project requiring substantial forced relocation will be situated. In other cases, a government may deny economic assistance to minorities, making it difficult for them to rebuild their homes and businesses after an environmental disruption.

Economic and demographic factors also influence whether and in what ways people affected by environmental disruptions will move. Economic and demographic factors affect both the decisions of individuals to move or stay and the capacity of governments to help those who remain. The greater the resources, the more likely it is that victims of environmental disruption will be able to remain where they are. For example, an individual who is no longer able to grow food but has resources to purchase food will not be as endangered as the individual who does not have those resources.

By the same line of reasoning, a country that has resources of its own or can purchase materials from other countries will be able to help its citizenry deal with the impacts of environmental disruptions while they remain at home. A wealthy country will more likely be able to airlift food to flooded areas to help farmers remain on their farms until the next growing season.

Population size and growth also affect a country's capacity to deal with environmental disruptions. A country with burgeoning population growth may find itself particularly unable to control the impact of environmental degradation on the capacity of its citizenry to sustain themselves. Migration may be one avenue open to the country in addressing both its population and environment problems, particularly if it also results in needed financial benefits from remittances paid by migrants.

Obstacles to migration include the difficulties a potential migrant may face in leaving the area of environmental degradation and the expected reception in a new location. The scale of both internal and international migration that results from a given environmental disruption will be determined by the ease with which people can leave and enter another region or country. For example, if large numbers of people from a given area have migrated 
in the past, people may be more willing to risk relocating in the event of an environmental disruption. On the other hand, individuals coming from more stable or sedentary societies may be less likely to move. Or, if flight requires a guide or some special means of travel, such as a boat or airplane, people may be less likely to depart. If individuals can leave by foot or a land vehicle, they may be more likely to seek new homes.

The reception they are likely to receive in the new location will also affect the decision to leave. Safe areas of their own country may be more appealing than venturing into foreign countries where the reception may be more questionable. On the other hand, if large areas of their own country are in the midst of civil conflict or also subject to the environmental disruptions, international migration may be the best solution. In the case of movements across a border, the willingness of the receiving country to admit the environmental migrants will often determine the size of the displacement. Under emergency circumstances the receiving country may have little choice but to open its borders. Migrants from slow-onset disruptions may find it more difficult to find a new home in a new country.

International disaster assistance often affects the extent to which individuals can survive without moving to a new location. The key issues are 1) whether assistance is made available in a timely manner, and 2) where and how it is provided. The timely availability of international assistance is dependent on having an effective system for providing early warnings of environmental disruptions; agreement on the part of donors and recipients that assistance is needed and will be permitted; and effective emergency response teams and resources. While famine and other environmental early warning systems function quite well in predicting problems, the latter two parts of this response capacity are often missing. In the case of Sudan, for example, recurrent predictions of famine were discounted by the government. Assistance offered by other governments and the United Nations were refused. In other cases, emergency responses have been delayed by a lack of funding and/or disagreements over which agencies had responsibility for providing assistance.

Where assistance is provided also affects population movements resulting from environmental causes. If assistance can reach individuals close to their homes, migration may be avoided. On the other hand, if there are major logistical or political obstacles to delivering assistance to the site of the problem, people may have no choice but to relocate to where they can obtain help. Further, the type of assistance will influence migration patterns. If people receive emergency rations but no means of replanting their land, for example, they may be unable to return to their land and may find themselves permanently displaced.

The funding policies and priorities of the institutions and governments that fund large-scale development projects such as dams, transportation networks, urban infrastructure, mining, etc. influence the extent to which these activities contribute to environmental degradation and/or the forced relocation of people without adequate plans. In the absence of comprehensive resettlement plans, the involuntarily displaced, deprived of livelihood and home, may be forced to make their own way to already overcrowded cities or rural areas. Such movements often result in social and environmental disruption in the communities that receive them. 
In response to these concerns, the World Bank over the past years has developed and refined policy guidelines and operational procedures to address the issues of involuntary displacement and environmental degradation. OECD has recently adopted these guidelines. While the guidelines have had a positive effect and continue to hold the potential to minimize human and environmental suffering, they are not always carried out uniformly or consistently. In addition, most countries and organizations have not developed similar guidelines.

The Bank guidelines state that "whenever feasible, involuntary resettlement must be avoided or minimized, and alternative development solutions must be explored." 11 In cases where involuntary displacement is deemed unavoidable, the Bank's policies and procedures concentrate on minimizing and reversing the negative effects of the involuntary displacement and on helping the displaced to become re-established as a productive and self-sustaining population.

To achieve this, the Bank requires governments to take responsibility for the resettlement and to involve the resettlers and the host population. It requires the comprehensive collection of information in order to develop well-informed resettlement plans that are integrated into every step of the project planning. These plans must be clarified between the Bank and the borrower before the negotiations for the project loan begin. The resettlement plans are required to include substantial development programs that ensure that the displaced population is integrated into its new community, regains at least its previous standard of living, and has the opportunity to become economically self-sustaining.

While the Bank has not adopted general environmental standards because of the great differences between member countries, the Bank's policy is to integrate environmental aspects into every step of the project design and operation.

\section{Categories of Movement}

Movements caused by environmental disruptions will have very different characteristics depending on the type of disruption and the combination of intervening factors that exist. Migration varies along a number of continuums, each of which influences the appropriate responses to the particular movement.

Whether a movement is on a small or large scale depends on the extent of the population subject to the environmental disruption. The size of environmentally-caused migrations can vary from a few individuals to mass departures involving millions of people. Small movements are usually easier to address than mass movements, except in situations where the migrants have specific characteristics or needs that create difficulties for the receiving communities such as particular ethnic or racial backgrounds, political affiliations, and health or other needs that require large outlays of financial resources.

11 Michael M. Cernea, "Involuntary Resettlement in Development Projects: Policy Guidelines in World Bank-Financed Projects," (World Bank Technical Paper Number 80, 1988), p. 4. 
Emergency versus slow-onset movements are a second variation. Some environmental disruptions, such as hurricanes or earthquakes, occur with little or no warning and require that people move quickly to get out of harm's way. Others develop more slowly and provide time for people to assess their options, leave in an orderly manner and even bring resources with them. At times, the disruption can be slow-onset but the resulting movements are of an emergency nature because of the intervening factors. For example, logging in Southern Thailand gradually stripped steep mountains of cover. Then in 1988 storms hit, unleashing disastrous mud slides that killed hundreds. Also, desertification may normally cause slowonset movements, but if combined with a civil conflict, it may result in emergency movements. If the fighting arrives in a particular area, people who had been coping with the desertification may find themselves no longer able to do so. They may then be forced to leave with little preparation.

Temporary, extended and permanent movements result from environmental degradation. In some situations, the environmental disruption causes a temporary inability for people to sustain themselves; the temporary dislocation may be of a few days or weeks duration, or it may be more extended, lasting years. In other cases, the habitat is permanently damaged and unable to sustain the population. While movement patterns generally follow the environmental pattern (that is, permanent disruptions lead to permanent relocation and temporary damage leads to temporary movements) intervening factors may result in permanent or very extended movements following temporary disruptions. For example, political factors may prevent minorities from returning to their homes after an elemental disruption, such as a flood, that would normally not cause permanent dislocation. Additionally, environmental damage to a specific location may be shorter-lived than a conflict that caused it, but once people have found safety as well as sustenance in another location, they may be unwilling to return to their homes until there is a peace settlement.

Internal and international movements may result from environmental disruptions. International migration is rarely people's preferred response to a situation that causes them to move. If they can find new homes within their own country, most victims of environmental disruptions will migrate internally. International migration may result from environmental degradation, however, if internal movements are precluded by political, economic or logistical factors. For example, it may be closer and less expensive to cross into another country if the environmental disruption occurs near the border. Or, civil conflict or human rights violations following environmental disruptions may precipitate the decision to move to another country, because it is believed that assistance is more likely to be available there. Further, the location of international assistance may determine whether an individual remains within his or her own country or goes to another. Feeding stations in a neighboring country may attract migrants while delivery of food internally may encourage people to remain.

\section{Assistance and Protection Needs of the Migrants}

Different movement patterns generate different needs for assistance and/or protection for the migrants and, as discussed in the next section, for the communities they enter. 
Emergency material assistance is needed in almost every large-scale disaster that requires people to relocate, even for a short period. Away from their own homes and livelihood, victims of environmental disasters need food, shelter, clothing, and, often, medical attention. When large numbers of individuals find it necessary to leave all of their belongings and venture far afield, the need for material assistance increases. Camps may need to be built to accommodate the newcomers. Under such circumstances, in addition to food and shelter, there is a need for sanitation systems, immunizations against such communicable diseases as measles, and other interventions to ensure that people who have survived the disaster do not succumb to disease. Depending on the level of trauma produced by the environmental disruption and resulting migration, counseling to deal with the post traumatic stress may be needed as well.

Longer-term care and maintenance may be needed if the displacement is extended and individuals are unable to support themselves in the new location. At this point, the range of assistance provided becomes more complicated. While food, shelter and health care continues to be required, other issues become of interest such as education for children and skills training and income generation opportunities for adults.

Assistance to return to their homes may be needed after temporary dislocations. The assistance needed will generally be greater the longer the individuals have been displaced and the further away they are from their homes. Assistance needs can vary from purely logistical ones - that is, help in traveling back to their homes -- to economic and political ones involving help in reintegrating into their home societies.

Legal and physical protection becomes an issue for environmental migrants if they cannot rely upon the laws and political structures of their own country to help them cope with their displacement. Those displaced for a combination of environmental and political reasons are usually most at risk, particularly if they are internally displaced and still subject to the governmental actions that caused them to move. Under such circumstances, their access to material assistance may be impeded. Environmental migrants who cross a border may also require protection if the receiving government does not permit them legal entry and their forced return would place them in danger. As will be discussed below, the lack of clear definitions as to which categories of environmental migrants are eligible for which types of protection creates special problems in addressing this issue.

Assistance in integration into a new community may be needed by environmental migrants who are unable or unwilling to return to their homes and are permitted to remain in a new location. If they have relocated within their own countries, they may require assistance in learning new skills if unable to resume the employment they had in their old communities. If they have moved to a new country, they may require language training, cultural orientation, and other services to help them adjust. 


\section{Environmental Impact on the Receiving Community}

Migration exerts a broad range of impacts upon the communities which receive the migrants. Some of the impacts are beneficial, such as bringing needed resources to the community. Other impacts are negative, particularly in the short-term when the migrants may not yet be contributing to the area. Impact aid may be requested by a community that has had to deal with the entry of large numbers of environmental migrants. The impacts often result from increased numbers of people using school systems, health care systems, the job market, the social service system, etc.

Of particular concern are the damaging effects large-scale migration can have on the environment of the receiving location. When large numbers of people move from one area to another, they can easily upset the delicate environmental balance of their new location.

"A visit to virtually any refugee camp or settlement area... is a sobering experience. As one approaches, one enters an empty expanse of many miles - dusty in the dry season, slick with mud after the rains - where trees, shrubs, and other vegetation have disappeared as refugees have scoured for firewood... Prolonged refugee stays deepen the dilemma. The government of the asylum country and the local population might regard a large refugee presence, with its effect on their resources, as an acceptable burden over the short run. But, even if they originally welcomed the refugees, they begin to express serious concern if they sense that they themselves are being continually crowded out and disadvantaged. They see their environment ravaged." 12

The nature of environmental change in the receiving community depends on specific circumstances but can be categorized according to the location of the settlement (urban or rural) and the size of the displaced population.

Refugee camps can approach the size of cities, even large ones. For example, there are about 180,000 people living in Site 2 along the Thai-Cambodian border, making it one of the larger cities in Thailand. It is not unusual for camps to be located where there is inadequate resources, particularly water and firewood, for the size of the population. These situations lead to deforestation as refugees utilize the limited supply of fuel for cooking and heating. The displaced population is likely to deplete other local supplies as well, driving up food prices. Competition with the local host population can become intense and be particularly damaging for poorer locals who may then decide to move, thereby creating another migration.

A number of projects have been funded to reduce the negative environmental impacts of refugees. The World Bank has funded projects to restore forests in Pakistan. Another project sought to develop more fuel efficient cooking facilities for refugees in Malawi in order to reduce the need for cutting trees for firewood.

12 "W. R. Smyser, "Refugees: A Never-Ending Story," Foreign Affairs (Fall, 1985). 


\section{POLICY AND PROGRAM ISSUES}

The complex nature of the relationship between the environment and migration raises a number of policy and program issues that are being inadequately addressed at present.

\section{Definitions: Environmental Migration? Environmental Refugees?}

The multi-causal nature of environmental migration and the variety of forms it can take make definitions and terminology difficult. Nevertheless definitions are important because they determine the degree of support and protection individuals receive in an emergency, the prospects for finding longer-term solutions, and the institutions charged with the responsibility to devise strategies and apply resources to address the situation.

As previously described, the term "environmental refugee" has been used to describe the whole category of people who migrate because of serious environmental disruptions that make their habitats unlivable temporarily or permanently. This broad definition, while evoking an image that has brought public attention to the issue, is not sufficiently precise for addressing the various types of movements that develop because of environmental degradation. International organizations, national governments and NGOs have specific mandates which limit the scope of their assistance on cross-cutting issues such as migration and the environment. Thus, the category to which a person is assigned can determine whether that person receives aid and/or protection from the international community or gains legal entry into another country. Definitions affect not only the way in which organizations aid the individual or group in need, but also the way in which institutions organize to raise funds, provide assistance, and cooperate among themselves.

Migration falls loosely into two categories: a) movements of people that are regulated by a government, and b) movements that are irregular - that is, in which the individual migrant makes the decision to relocate and does so without reference to a government's laws and regulations regarding exit or entry. For the most part, the first type of migration is deemed beneficial to all parties. It includes the movements of tourists, business people, students, people seeking family reunification through regular immigration channels, and migrant workers. It is the second type of migration that is more controversial. Irregular movements across national boundaries are difficult to control, particularly in their size, method and impacts on the receiving communities.

Migration caused by environmental disruptions is not a recognized category in international law or in most national law. The environmental migrant may overlap, however, with recognized groups that have been defined in international law. In fact, an individual leaving his or her home because of environmental disruptions may be, but not necessarily is, 
a refugee under international and/or national law. The 1951 United Nations definition of a refugee, as amended by the 1967 refugee protocol, is:

"any person who, owing to a well-founded fear of being persecuted for reasons of race, religion or political opinion, is outside the country of his nationality and is unable or, owing to such fear, is unwilling to avail himself of the protection of that country."

The operative word in this definition is "persecution." The refugee definition was aimed at providing protection to individuals who could not return to their home countries because of human rights violations or other actions taken against them by their government. To the extent, then, that an environmental migrant fears persecution, he or she will be covered by the refugee convention regardless of whether the environmental disruption or the human rights abuse precipitated the actual flight.

The 1969 Organization for African Unity convention expanded the definition of a refugee within that continent to include still further categories of migrants: 13

"..every person who, owing to external aggression, occupation, or foreign domination or events seriously disturbing public order in either part or whole of his country of origin or nationality is compelled to leave his place of habitual residence in order to seek refuge in another place outside his country of origin or nationality."

To the extent that environmental disruptions "seriously disturb public order," the victims of these events may be considered refugees by the OAU definition.

In both of these definitions, a key ingredient is the relationship between the migrant and his government. Where a government is willing and able to assist its citizenry in coping with an environmental disruption and is able to maintain public order in doing so, people compelled to move in order to benefit from this assistance would not fit the refugee definition. That is not to say that the individual migrant would not necessarily need international assistance, particularly if his or her government is poor. Rather, it is to emphasize that central to the notion of a refugee is the need for protection not just assistance. In fact, the system of international protection and assistance for refugees has developed precisely because of the political dimensions of these movements: refugees, unlike others who move, require outside protection because of the actions, or in some cases inactions, of their own countries against them.

Once the case is made for using the refugee definition in a precise way to include only those environmental migrants who require protection from their governments, a further complication becomes apparent. The international definition of a refugee includes only those individuals who have been forced to cross an international border. It does not include those who are internally displaced, even if their reasons for moving would have made them refugees had they left their countries. Environmental migrants may fall into this refugee-like

13 The Cartegena Declaration, adopted by Central American governments, uses a similar definition of a refugee. This definition is not generally recognized in Europe, the United States, Canada, or Australia. Some of these countries do recognize people in the OAU/Cartegena category as being in need of safe haven or other form of humanitarian relief from deportation. 
category of internally displaced person. To a large extent, these internally displaced persons are the most vulnerable among the environmental migrants: unable to avail themselves of the protection of the government (or a resistance force that controls their areas of residence), often denied access to international assistance, and unable to return home because environmental disruptions (sometimes caused by the government or the resistance as part of a civil conflict) have destroyed the habitat.

To summarize, drawing a clear distinction between an "environmental migrant" and an "environmental refugee" is important because these distinctions go to the heart of understanding the causes of these movements as well as the potential responses to them. While environmental migrants may require humanitarian assistance from the international community, environmental refugees, whether internally or internationally displaced, would need protection as well.

\section{Migration Policies}

Few countries have established policies for handling migration resulting from environmental disruptions. Just as the term has not found its way into the prevailing definitions, this category of migrants is not covered by most national laws--except in so far as the environmental migrant also meets a recognized definition such as a refugee.

As an issue, the adequacy of migration policies is being debated in the developed countries more so than the developing ones. For many developing countries faced with large-scale migration, the primary issue is the level of assistance that will be available to help cope with the problem. For many developed countries, the primary issue is the admissibility of the individual migrant.

Migration policies cover the admission of people for temporary and permanent residence. Worldwide there are many opportunities for temporary, regulated entry for business, tourism or studies, but relatively fewer opportunities for permanent legal relocation. Most countries limit their formal immigration programs to reunification of nuclear families. The major immigration countries also provide admission numbers for people who meet their labor market needs. Few permanent admission slots are available on humanitarian grounds, with the majority of these going to people who are determined to be refugees under international law or of special concern to the receiving country.

For many would-be migrants, the principal entry route into the countries of Europe and North America has become the asylum system. The migrants present themselves to immigration authorities and request permission to remain in the country because they fear persecution if returned. The industrialized countries have developed rather elaborate systems for determining if the individual applicant meets the refugee definition. If he or she does, permission to remain is granted. If not, the individual is subject to deportation.

At present, denial rates in most asylum systems are high. Few applicants meet the persecution test. There are often other grounds, however, upon which the migrants are 
permitted to remain, at least temporarily. These include other humanitarian reasons: for example, the individual, while not a specific target of persecution, may have left a civil war that poses general dangers to the residents of the country.

Nations vary as to the extent that they utilize formal mechanisms to provide temporary admission to people who are of humanitarian concern. The United States, for example, has a legislated Temporary Protected Status that allows the government to designate certain nationalities as eligible for the status because of conditions in their home countries. Serious environmental disruptions are a ground upon which TPS can be triggered. Other countries make similar designations at the national level to permit groups or individuals to remain. Still others leave it to local authorities to determine on a case-be-case basis if an individual applicant should be allowed to stay for humanitarian reasons.

The migration and refugee policies of most of the industrialized countries are under increasing scrutiny. There is an appearance that these systems are out of control. The growing number of asylum applicants combined with the high cost of the adjudication process (estimated at $\$ 5$ billion in the OECD countries) has raised questions about the adequacy of the definitions used and the policies and procedures in operation. 14 Should migration because of serious environmental disruptions grow as predicted, these movements will place one more pressure upon an already faltering system.

\section{Organizational Roles, Relationships and Responsibilities}

An array of organizations are currently involved in developing policies and/or providing assistance and protection to environmental migrants. These institutions include U.N. agencies, government agencies and non-governmental organizations. For most, however, work with environmental migrants is only a small part of their mandate. No agency has the responsibility to oversee the issue of environmental migration through all of its phases.

Both the environment and migration cross national boundaries, making the issue of environmental migration a natural one for the agenda of intergovernmental organizations and non-governmental agencies that operate internationally. Following is a listing of the main international actors currently involved in and their mandates for environmental migration issues:

U.N. Environment Program's (UNEP) mandate is primarily to stimulate and coordinate environmental action. UNEP monitors changes in the environment, analyzes environmental trends, and promotes actions to safeguard ecologically sensitive areas. UNEP has already taken a lead role on the issue of environmental migration by commissioning the 1985 report referenced at the beginning of this paper. A second report on the issue is in progress.

14 Jonas Widgren, "International Migration and Regional Stability," International Affairs, 4 (1990), p. 751 . 
Office of the U.N. Under-Secretary-General for Humanitarian Affairs and Emergency Relief Coordinator, a newly created department, is charged with coordinating responses to natural and human-made disasters. The U.N. Disaster Relief Organization (UNDRO) has been incorporated into this new department. UNDRO has played a role in coordinating relief for natural disasters and in promoting disaster mitigation. It helps countries prepare for and reduce the effects of natural and human-made disasters.

U.N. Development Program (UNDP) channels development assistance to developing countries. Working with 150 developing countries, UNDP has a broad presence in the Third World. Its primary role is in promoting environmentally-sound development projects that could help reduce the root causes of environmental migration. UNDP, in its role as the Resident Representative of the U.N. in each country, also has the mandate for coordinating assistance to internally displaced persons.

U.N. High Commissioner for Refugees (UNHCR) has principal responsibility for assisting and protecting refugees. To the extent that environmental migrants are also refugees, UNHCR has a clear mandate for assisting and protecting them. Using its good offices, UNHCR has provided assistance to other environmental migrants as well.

International Organization for Migration (IOM), although not a part of the United Nations, works closely with these other intergovernmental organizations. IOM has played an important role in providing health services for migrants as well as transport services to help them relocate. IOM also convenes fora for the discussion of migration issues.

World Bank is one of the primary funders of projects that hold the potential for creating large-scale displacements. The World Bank has developed guidelines for development projects that cause forced resettlement. These guidelines, which have also been adopted by the Organization for Economic Cooperation and Development, provide criteria for determining if the project is justified, given the uprooting that would take place, and require that there be provisions for the relocation of the displaced populations.

Other U.N. agencies have roles to play as well in developing policies and/or program responses to environmental migration: U.N. Fund for Population Activities (UNFPA) supports projects on basic population data, population dynamics, population policy, family planning, communications and education, and program development. World Health Organization (WHO) provides medical relief to disaster victims. World Food Program provides emergency food aid to refugees and displaced persons. UNICEF, through its mandate to assist women and children, becomes involved in emergency programming for victims of disasters, refugees and displaced persons. The U.N. Human Rights Commission and the U.N. Centre for Human Rights monitor situations in which human rights abuses may be responsible for environmental disruptions or their resulting migration.

The Red Cross also plays a role. The International Committee of the Red Cross is involved with people forced to flee because of armed conflict. In its role in monitoring implementation of the Geneva Conventions, it is also concerned with reducing the incidence of environmental warfare. The International Federation of Red Cross and Red Crescent Societies helps coordinate the activities of national Red Cross and Red Crescent societies. 
These organizations are often the first groups on the ground providing emergency assistance to the victims of environmental disruptions.

Other non-governmental organizations also provide assistance to people uprooted as a result of environmental disruptions. These agencies play an important role in providing health care, food distribution, sanitation work, and other needed services.

Although there are a range of actors who could play an important role internationally regarding environmental migration, the system in its totality does not function very well. A variety of problems impede the international community's capacity to respond quickly and effectively to these situations. At the heart of the problem are four principal issues: unclear mandates, lack of coordination, lack of resources and seemingly competing or contradictory interests of the organizations concerned with environmental migration.

Unclear mandates impede international actions to address the causes of environmental migration, provide effective early warning of imminent disasters, get assistance and, where needed, protection to the victims of environmental disruptions, and find solutions for those forced to move. No single agency has a clear mandate regarding environmental migration. While a number of intergovernmental organizations have related mandates, none has the clear lead responsibility for addressing this issue.

Most important, international agencies do not have a clear mandate to intervene with governments when governmental actions are precipitating the types of environmental disasters that lead to large-scale internal or international movements. Both carrots and sticks are needed to encourage more responsible actions on the part of governments. For example, government requests for funding of development projects need to be evaluated in terms of the environmental damage likely to be caused, the numbers of potential migrants, and the plans for assisting the migrants relocate. The World Bank has developed guidelines that could serve as a model for other agencies in assessing projects that result in involuntary relocations of populations.

Internal displacements that result from government actions that destroy the environment (such as mining of fields or use of chemical defoliants) are perhaps the most difficult to address given the mandate issue. Some nations have denied that there is a problem and have refused international help as an infringement of their national sovereignty. While such countries can be taken to task for their violations of human rights, the United Nations does not at present have the mandate to intervene against their will to help the displaced citizenry, although some would argue that mandate is implicit in the U.N. Charter.

Lack of coordination has plagued a number of international efforts to provide assistance and protection early in a crisis. With so many potential actors and no designated leader, it is particularly important that there be cooperation among the various players in responding to an environmental disruption and its resulting movements. Instead, there have been situations where agencies overlapped in responding to some needs while others went unmet. The establishment of the new office of the Emergency Relief Coordinator in the U.N. should help address this problem. 
Inadequate resources to respond to environmental emergencies is a further problem in the international system. Needed resources include money and trained staff who can be deployed quickly to provide assistance to the victims of environmental disruptions. Resources are needed to help those who can remain at or near the site of the environmental disruption to do so and then to help them reestablish themselves as quickly as possible. Where it is impossible for people to remain, resources are needed to move people in as orderly a way as possible and to find alternative residences and livelihoods for them.

Seemingly competing or contradictory interests of the various actors involved in environmental migration issues impedes the development of effective working relationships. For example, some population and environmental groups in developed countries have promoted restrictions on immigrant admissions because of a concern that additional population will deplete resources. Some development agencies have been reluctant to join with environmentalists because of a concern that environmental concerns will be used to impede development in the countries in which they operate. Human rights groups have generally concerned themselves with political and legal rights of individuals, paying little attention to the right to a sustainable environment. Since environmental migration, as discussed, overlaps with each of these areas --environment, migration, development, population and human rights -- it is critical that the various groups begin to work cooperatively to address this issue.

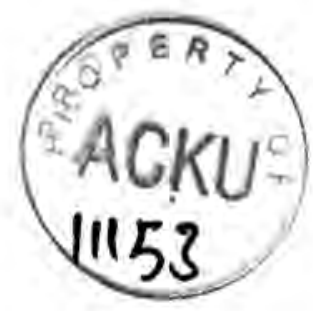




\section{CONCLUSION}

Ways must be found to enable policy makers and planners to design and implement programs that promote more rational use of the environment. At the same time, it is important to keep in mind that large numbers of people, even with a concerted effort to remedy environmental deterioration, will be forced from their homes in the coming years because they will not be able to sustain themselves. With a clearer understanding of the relationships between the environment and migration, the goal should be to minimize mass environmental movements while handling those that occur with rational, humane policies.

This paper is an attempt to raise policy issues that need to be addressed in order to prepare a more effective response to what is likely to be a growing phenomenon. An agenda for the future would include:

- the need to give special focus to addressing the causes of environmental migration and to developing strategies that recognize the complex and interlocking issues that prompt these movements;

- the need to anticipate possible migration scenarios emanating from environmental disruptions and to develop a range of responses that are appropriate to the specific circumstances of the scenarios that are unfolding;

- the need for greater transnational cooperation and coordination in addressing environmental migration issues, involving the sending and receiving countries as well as the major international and regional organizations;

- the need to develop more cooperative working relationships among environmental, migration, development, population and human rights groups to address the issue of environmental migration;

- the need to develop a better understanding of the development/ environment/migration chain of events in order to devise alternative policy approaches;

- the need to develop strategies to provide assistance to the victims of environmental disruptions in a manner that reduces their need to migrate in order to reestablish their lives;

- the need, when movements are inevitable, to develop strategies to provide assistance to help the uprooted return to their areas of residence or to integrate into new communities; 
- $\quad$ the need to develop strategies to provide assistance to receiving communities, where required, in order to help them deal with the impacts of large-scale environmental migration;

- the need to reexamine existing migration and refugee policies with an eye towards their adequacy in handling what may be large-scale environmental migrations in the future;

- the need to define and, if necessary, develop new international instruments for providing assistance and, if needed, protection to victims of serious environmental disruptions, regardless of where they seek safety.

30 


\section{REFERENCES}

Africa Tomorrow: Issues in Technology, Agriculture and U.S. Foreign Aid - A Technical Memorandum. Washington, DC: U.S. Congress, Office of Technology Assessment, OTA-TM-F-31, December 1984.

Barraclough, Solon and Krishna Ghimire. The Social Dynamics of Deforestation in Developing Countries: Principle Issues and Research Priorities. United Nations Research Institute for Social Development. Discussion Paper 16. Geneva, Switzerland: United Nations, November 1990.

Brown, Lester R. et. al. State of the World 1991. New York: W.W. Norton and Company, 1991.

Center for International Development and Environment. Directory of Country

Environmental Studies 1990. World Resources Institute, April 1990.

Cernea, Michael M. Involuntary Resettlement in Development Projects: Policy Guidelines in World Bank-Financed Projects. World Bank Technical Paper, No. 80, 1988.

Conable, Barber B. "Development and the Environment: A Global Balance." Finance and Development. December 1989.

Cowen, Robert C. "More of Us, More Problems." The Christian Science Monitor. p. 9.

Department of International Economic and Social Affairs. International Transmission of Population Policy Experience. (Proceedings of the Expert Group Meeting on the International Transmission of Population Policy Experience, New York City, June 2730, 1988.) New York: United Nations, 1990.

. Population Growth and Policies in Mega-Cities: Bombay. Population Policy Paper No. 6. New York: United Nations, 1986.

- Population Growth and Policies in Mega-Cities: Cairo. Population Policy Paper No. 34. New York: United Nations, 1986.

- Population Growth and Policies in Mega-Cities: Seoul. Population Policy Paper No. 4. New York: United Nations, 1986.

Dixon, John A., Lee M. Talbot and J.-M. Le Moigne. Dams and the Environment, Consideration in World Bank Projects. Washington, DC: The World Bank, 1989. 
Economic and Social Commission for Asia and the Pacific. Environmental News Briefing: A Selection from the Region's Press. Vol. 5, No. 4, Bangkok, Thailand: April 1991.

. Environmental News Briefing: A Selection from the Region's Press. Vol. 5, No. 3, Bangkok, Thailand: March 1991.

- Global and Environmental Problems of the Depletion of the Ozone Layer, Climatic Change and the Rise in the Sea Level: Their Implications in the Context of the Asian and Pacific Region. (A preparatory meeting of Senior Officials.) Bangkok, October 10-13, 1990.

- Greening Development: Report of ESCAP/UNDP Meeting of Eminent Persons on the Greening Development Process. Bangkok, October 9-11, 1989.

- Internal Migration in Asia and the Pacific. ESCAP Population Bibliographic Series: Number 4, Bangkok, Thailand: United Nations, 1984.

. Internal Migration and Structural Changes in the Labour Force. Asian Population Series No. 90, Bangkok, Thailand: United Nations, 1988.

. Population Headliners. No. 194 ISSN 0252-3639, Bangkok, Thailand: United Nations, May 1991.

. Population Headliners. No. 193 ISSN 0252-3639, Bangkok, Thailand: United Nations, April 1991.

. Population Research Leads. No. 36 ISSN 0252-4503, Bangkok, Thailand: United Nations, November 1990.

- Report of the ESCAP/UNDP Expert Group Meeting on Population, Environment, Resources and Sustainable Development. Thailand, May 18, 1991.

- Report of the Ministerial-Level. Conference on Environment and Development in Asia and the Pacific. Bangkok, Thailand, October 15-16, 1990.

- Trends in Migration and Urbanization in Selected ESCAP Countries. Bangkok, Thailand: United Nations, 1988.

. Waterlogging and Salinity Control in Asia and the Pacific. Bangkok, Thailand: United Nations, May 1990.

El-Hinnawi, Essam. Environmental Refugees. Nairobi: United Nations Environment Programme, 1985.

"Emergency in the Environment." World Food Programme Journal. Number 12, OctoberDecember 1989, pp. 18-19. 
Harrison, Paul. "Healthy Land - Healthy People." Earthwatch. Number 13, 1990.

Helin, William H. Refugees and Forestry. Paper prepared for the Forestry Support Program, April 1990.

Helin, William and Susan Tamondong-Helin. "Migration and the Environment: Interrelationships in Sub-Saharan Africa." Field Staff Reports. Universities Field Staff International and the Natural Heritage Institute, No. 22, 1991.

Hutchison, Robert A. Fighting for Survival. Gland, Switzerland: International Union for Conservation of Nature and Natural Resources, 1991.

"Immediate Crises." FEWS Bulletin. Number 4/91, June 3, 1991.

"In a Warming World, Who Comes Out Ahead?" The New York Times. February 5, 1991.

Independent Commission on International Humanitarian Issues. The Encroaching Desert.

London: Zed Books Ltd., 1986.

. The Vanishing Forest. London: Zed Books Ltd., 1986.

. Famine: A Man-Made Disaster? London: Pan Books, 1985.

"Integrating Environment, Development and Population: A Global Agenda." Impact. No. 13, Winter-Spring 1991, p. 1.

Islam, Muinul. Ecological Catastrophes and Refugees in Bangladesh. Paper prepared for Conference on Worldwide Refugee Movements, Development, Politics and Human Rights. New York, November 8-9, 1991.

Jacobsen, Jodi L. Environmental Refugees: A Yardstick of Habitability. Worldwatch Paper 86 , November 1988.

Keller, Bill. "Developers Turn Aral Sea Into Catastrophe." The New York Times. Section C, December 20, 1988, p. 1.

Lazarus, David. "Environment: New Strangers at the Door?" Refugees. Public Information Service of the United Nations High Commissioner for Refugees, No. 81, December 1990, pp. 14-15.

Maloney, Clarence. "Environmental and Project Displacement of Population in India, Part I: Development and Deracination." Field Staff Reports. Universities Field Staff International and the Natural Heritage Institute, No. 14, 1990-91.

- "Environmental and Project Displacement of Population in South Asia, Part II: Land and Water." Field Staff Reports. Universities Field Staff International and the Natural Heritage Institute, No. 19, 1990-91. 
Maloney, C. and K. V. Raju. Environmental Refugees in India. Paper, January 1992.

Martin, Susan Forbes. "The Inhospitable Earth." Refugees. Public Information Service of the United Nations High Commissioner for Refugees, No. 89, May 1992, pp. 12-15.

Michaels, Pete S. and Steven F. Napolitano. "The Hidden Costs of Hydroelectric Dams." Cultural Survival Quarterly. Vol. 12, No. 2, 1988, pp. 1-4.

Overseas Development Administration. Briefing Paper 3: British Aid and the Environment. United Kingdom, September 1990.

. The Environment and the British Aid Program. United Kingdom: S. W. Sharman \& Co. Ltd., May 1990.

Russell, Sharon Stanton, Karen Jacobsen and William Deane Stanley. International Migration and Development in Sub-Saharan Africa, Volume I: Overview. World Bank Discussion Papers, Africa Technical Department Series 101. Washington, DC: World Bank, October 1990.

- International Migration and Development in Sub-Saharan Africa, Volume II: Country Analyses. World Bank Discussion Papers, Africa Technical Department Series 102. Washington, DC: World Bank, October 1990.

Sanders, Thomas G. "Northeast Brazilian Environmental Refugees Part I: Why They Leave." Field Staff Reports. Universities Field Staff International and the Natural Heritage Institute, No. 20, 1990-91.

. "Northeast Brazilian Environmental Refugees Part II: Where They Go." Field Staff Reports. Universities Field Staff International and the Natural Heritage Institute, No. 21, 1990-91.

Stahl, Michael. Constraints to the Environmental Rehabilitation Through People's Participation in the Northern Ethiopian Highlands. United Nations Research Institute for Social Development Discussion Paper 13. Geneva, Switzerland: United Nations, July 1990.

Trolldalen, Jon Martin. Environmental Refugees. Oslo: World Foundation for Environment and Development, 1992.

Tyler, Christian. "Worse than Chernobyl." International Financial Times. Section 11, July 29-30, 1989, p. 1.

United Nations Development Program, Central Evaluation Office. UNDP/UNDRO Cooperation: An Evaluation. December 1989, p. 19.

United Nations Environment Programme. UNEP Newsletter Asia-Pacific. Vol. 8, No. 1, January-March 1991. 
- UNEP Newsletter Asia-Pacific. Vol. 7, No. 4, October-December 1990.

Westing, Arthur H., Ed. Explosive Remnants of War. London: Taylor and Francis, 1985.

- Environmental Warfare: A Technical, Legal and Policy Appraisal. London: Taylor and Francis, 1984.

Winterbottom, Robert. "Environmental Action Plans for the Greening of Africa." People. Vol. 18, No. 1, 1991, pp. 9-13.

35 


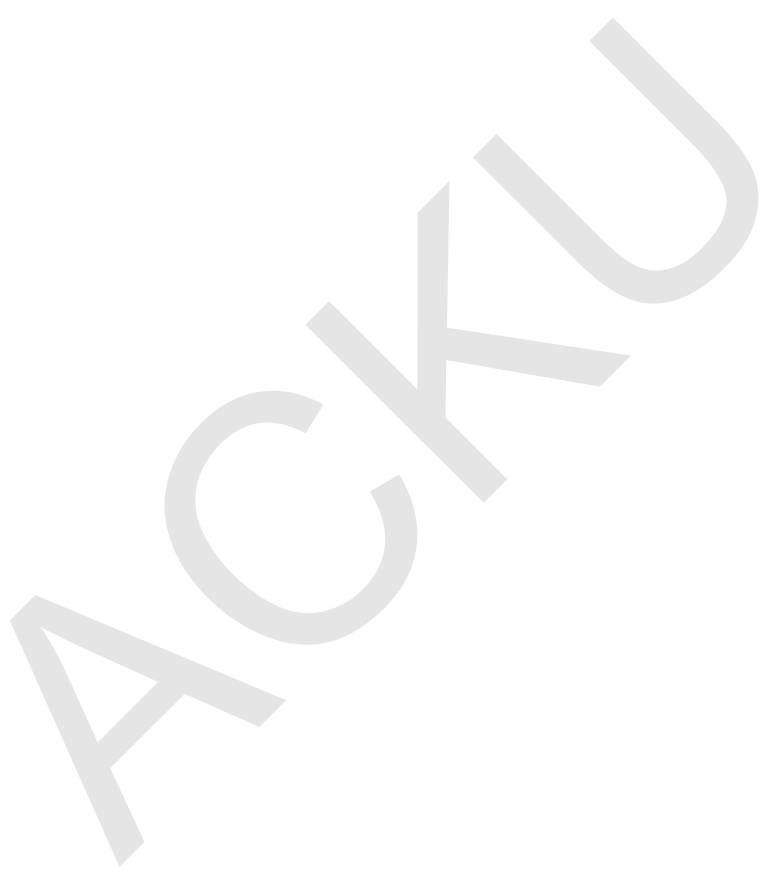




\section{SECTION TWO}

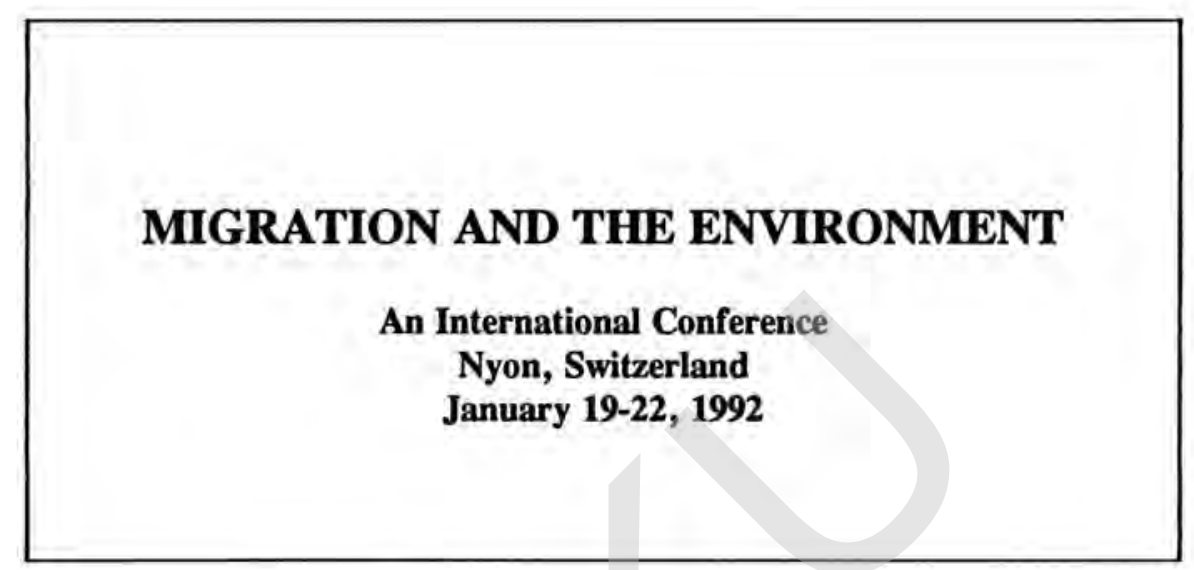

CONFERENCE REPORT

Organized by:

Swiss Departement of Foreign Affairs The International Organization for Migration The Refugee Policy Group 


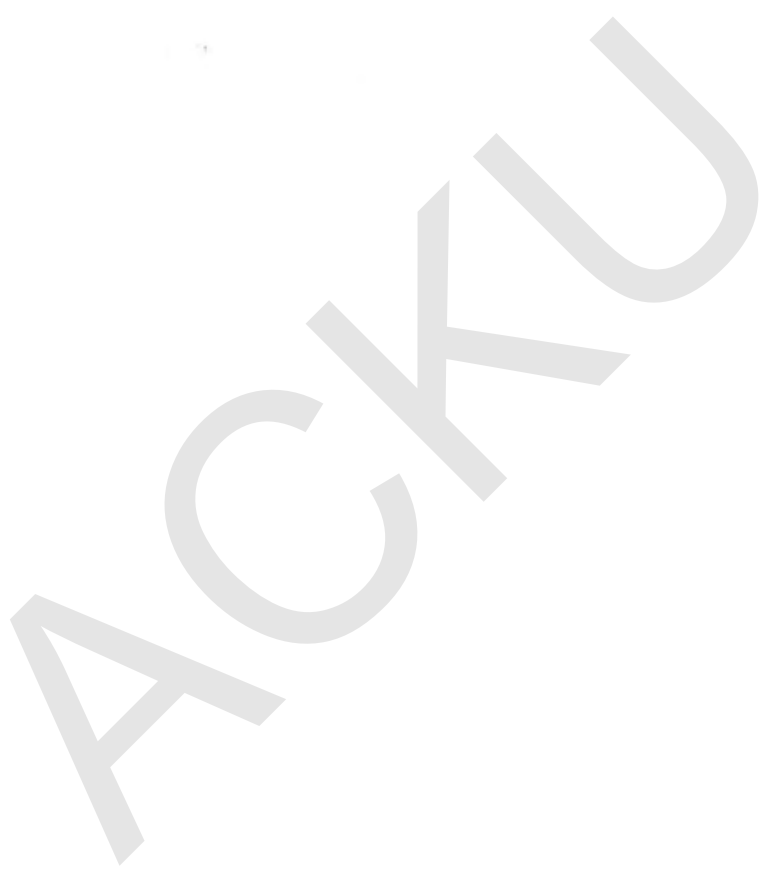




\section{ACKNOWLEDGEMENTS}

This conference was jointly sponsored by the Swiss Department of Foreign Affairs, the International Organization for Migration (IOM) and the Refugee Policy Group (RPG). The funds to support the conference, held in Nyon, Switzerland, were provided by the Swiss Department of Foreign Affairs.

Special appreciation is expressed to Ambassador Weiersmuller, of the Department of Foreign Affairs, who both encouraged the convening of the conference and served as cochair, along with James Purcell of IOM and Dennis Gallagher of RPG. 


\section{INTRODUCTION}

A meeting of 50 international experts was convened by the Swiss Department of Foreign Affairs, the International Organization for Migration (IOM) and the Refugee Policy Group (RPG) to address the interconnections between migration and environmental issues. Large numbers of people are already moving as a result of environmental degradation and these figures could increase substantially if larger areas of the earth become uninhabitable because of deteriorating environmental factors. Large-scale migration in turn affects environmental change, causing both problems and opportunities for the receiving communities.

Sessions of the meeting were chaired by Ambassador Rudolf Weiersmuller, the Swiss Coordinator for International Refugee Policy; Mr. James Purcell, Director-General of IOM; Ambassador Richard Benedick, former U.S. Ambassador-at-Large for Population Issues; and Mr. Dennis Gallagher, Executive Director of RPG. Mr. Nitin Desai, Deputy SecretaryGeneral of the U.N. Conference on Environment and Development (UNCED), made the keynote address.

The participants included environmental and migration specialists, officials of governments and intergovernmental organizations, and representatives from nongovernmental organizations. Participants came from Australia, Bangladesh, Canada, Egypt, Germany, India, Malaysia, Norway, the Philippines, Senegal, Switzerland, the United Kingdom, and the United States. 


\section{UNCED AND MIGRATION ISSUES}

Ambassador Weiersmuller opened the meeting. He introduced Mr. Desai, asking him to discuss the UNCED process and the role of migration in the deliberations.

Mr. Desai noted that migration was not currently on the UNCED agenda. Recognizing the importance of actual and potential population movements resulting from environmental degradation, he acknowledged, however, that a number of governments and nongovernmental organizations have evidenced interest in having UNCED address the interconnections arising between environmental issues and migration.

UNCED is scheduled for June 1992 in Brazil, the site of large-scale internal movements because of environmental degradation. The agenda is broad, in keeping with the focus on environment and development. UNCED itself is being preceded by four preparatory meetings. At UNCED, governments will be seeking to enunciate a statement of principles -An Earth Charter. In addition, UNCED will seek agreement on a cooperative agenda for action. More than 100 concrete programs have been proposed, requiring global partnership to implement. Under the name Agenda 21 --referencing the 21 st century - this agenda is meant to prepare the world for the environmental and development challenges of the future. The agenda includes plans for revitalizing growth and development in Third World countries that are facing major economic pressures; global initiatives for overcoming the linkages between poverty and environmental degradation; programs dealing with health, education and other strategies to help countries address underlying poverty in areas with fragile ecosystems; standards regarding consumption patterns; programs to reduce population pressures; and the management of human settlements, particularly in urban areas.

Agenda 21 would be looking simultaneously at a range of constraints on sustainable development and recommending strategies for overcoming those problems. Included will be financing strategies, technology transfer and scientific exchange. UNCED will also look at decision-making structures and make recommendations for improvements that would better support sustainable development. Substantial resources will be needed to mount such a program. Burden-sharing between the North and South will be required to help the developing countries do their part in protecting the global environment.

Mr. Desai noted that the agenda being discussed could go a long ways towards reducing migration pressure from both environmental degradation and under-development. He recognized that there is still likely to be stress on the environment that will lead to some, potentially high, level of migration. He urged that further attention be paid to the emergency management systems and strategies needed to cope effectively with these population movements. He stated that the UNCED proceedings would benefit from a better understanding of the issues to be discussed at the conference. 


\section{CAUSES, NATURE AND SCALE OF ENVIRONMENTAL MIGRATION}

In opening the session, IOM Director General Mr. James N. Purcell, Jr. underscored that discussions about the interconnections between the environment and migration are relatively new and reflect some basic weaknesses in current approaches for addressing migration pressures. Systems have developed multilaterally for dealing with movements of political refugees and bilaterally for dealing with migration for labor reasons and family reunification. In between, however, are large-scale movements that fit neither category of migration. He was referring to irregular movements where people did not meet the international legal definition of a refugee but were also not voluntary migrants seeking an improved lifestyle. Falling through the cracks of the current system are individuals who have been forced from their homes because of extreme poverty, warfare, environmental degradation and other similar reasons. He welcomed the discussions to come as a way to focus greater attention on resolving the causes and consequences of such migration.

Susan Forbes Martin, RPG Senior Associate, provided an overview of the issues to be discussed, based on a background paper that was distributed to participants before the meeting. She noted the need to develop a framework for better understanding the interconnections between the environment and migration if progress is to be made in ameliorating the causes or responding to those movements that cannot be averted. The components of such a framework would include not only the immediate causes of the movements but also the factors underlying the environmental degradation and the determination to move, such as political, security, and human rights situations, economic factors, demographics, and the obstacles and opportunities for migration.

Dr. Martin noted in her remarks that RPG had purposefully avoided using the term "environmental refugee" to characterize the entire category of people who are forced to move because of environmental change. Although environmental refugee has gained some vogue in both environment and migration circles, it does not adequately represent the complexity of the issues to be addressed. Within international law, refugees are defined as individuals who flee because of a well-founded fear of persecution and cannot rely on the protection of their own government. While some victims of environmental degradation may fall into that category of people, others do not. Using the term refugee to refer to all people forced to leave their homes because of environmental change loses the distinctions, particularly in terms of what can and should be expected in terms of the willingness and ability of the person's government to provide help and protection.

Substantial agreement was expressed among conference participants that large-scale population movements caused by environmental degradation is a current reality and future prospect. One participant noted that regardless of the terminology used, it should be 
recognized that millions of people have already been displaced because of environmental damage and millions more are at risk.

Two schools of thought emerged as to how the causes of these movements should be categorized. Some participants emphasized that environmental degradation is the proximate cause of population displacements whose underlying causes are a combination of poverty, overpopulation, conflict and political insecurity. These root causes contribute to the environmental decline which then forces people to move. Underdevelopment and rapid population growth, in particular, create the impetus for inappropriate resource utilization which in turns harms the environment. Poverty, overpopulation and repressive governmental policies also make it more difficult for individuals to cope with natural and other environmental disasters, thereby precipitating movements. Those who are in a particularly marginalized position within a society (for example, an ethnic or religious minority) will find it very difficult to obtain the resources necessary to overcome problems caused by environmental degradation. One participant argued that environmentally-induced movements should be labelled as resulting from unsustainable development.

Those holding the second perspective agreed that environmental degradation was often a manifestation of these other factors but argued for the utility of maintaining a separate designation. The environmental causes are important as determinants of when individuals will move, the specific circumstances under which their movements will take place and the responses needed to deal with the migration. One participant noted that environmentallydriven migration (as compared with poverty or demographically driven movements) had unique aspects. In particular, people leaving areas with significant environmental degradation may be unable to return to those areas absent a major effort to reclaim the environment. Another participant, agreeing with this point, remarked that a key to addressing environmental migration is rehabilitation of lands so that people will again be able to have control over their lives.

Other participants remarked that the concept "environmental migration" was useful in setting out an action agenda because it referred to a concrete set of factors. Underscoring the environmental causes would have political advantages because of the growing interest in environmental issues. Also, there is growing recognition that environmental problems are transnational; actions taken by one country affect the environment of another. The migration resulting from environmental harm should also be viewed as an issue of international concern.

There was some support for a dual approach which would examine root and proximate causes. The root causes are important to understand if effective measures are to be developed to reduce the environmental degradation. On the other hand, the proximate causes must be understood to avert forced migration, where possible, and address the reality of movements that cannot be stopped.

Consideration was given to the types of movements that had environmental degradation as their root or proximate cause. A distinction was made between emergency movements and slow-onset causes and movements, with the general reflection that the latter presented more conceptual and practical problems than the former. There has been substantial experience in 
addressing emergency movements caused by natural disasters or accidents. These events are difficult to predict in terms of specific time and location, but there has been progress in developing contingency plans in locations where there are recurrent disasters. Institutions such as the Red Cross and Red Crescent societies have well-planned emergency responses which they can put into place within a relatively short time.

By contrast, less is known about movements resulting from slow-onset environmental degradation. One participant spoke of the potential for four new horseman of the apocalypse: global warming, deforestation, rising sea levels and overpopulation. These phenomena could potentially displace millions of people from areas that will cease to be habitable. He noted that the world population is currently at five billion people and growing rapidly. Another participant remarked that the rate of population growth appeared to be at the heart of the problem. Where population is doubling within a generation but the economy is growing by less than three percent per year (i.e., doubling in less than 23 years), countries do not have the capacity to enable their citizens to deal with emerging environmental problems.

One participant spoke of a threshold that may soon be passed beyond which it will be impossible to reverse current trends towards massive destruction of the environment. Several others also emphasized the need to intervene now. One participant remarked that today's slow-onset problems could become tomorrow's emergencies if steps are not taken to prepare for potential displacements. Two challenges need to be met in addressing slow-onset situations: finding ways to avert movements by dealing with the causes of environmental degradation and preparing for those movements that cannot be averted.

The manner in which people move is an additional dimension categorizing environmentally-driven migration, participants noted. Several participants emphasized that environmental migration is characterized by forced displacement; the victims of environmental degradation have little if any choice about whether or when they should leave. One of the reasons that the terminology to describe environmentally-induced population movements is controversial, one participant stated, is that "migration" does not sufficiently denote that these people have been forcibly uprooted. While the term "refugee" may be inappropriate for the entire category of environmental migrants because of the international legal aspects to the definition, it reflects more accurately the involuntary nature of the movements. 


\section{CASE STUDIES OF ENVIRONMENTAL MIGRATION}

Several participants presented case studies of situations in which substantial environmental migration has taken place.

Thomas Sanders discussed population movements in and from northeast Brazil. He noted that UNCED is taking place in a country with substantial environmental migration; UNCED delegates will be "rubbing shoulders with the northeast Brazilian migrant phenomenon." The northeast part of the country is composed of nine states with a population of 43 million. About 20 percent of the population has left the region, with substantial numbers of inhabitants relocating to other parts of the northeast. Much of this movement has been from rural to urban areas and from interior to coastal parts of the northeast.

The most prominent environmental factors affecting this massive population displacement are drought and soil depletion. The interior is a semi-arid zone where drought is common while the coastal area is more fertile. Irregular rainfall is the cause of drought which makes planting and growing of crops difficult. This natural phenomenon is compounded by the relative poverty and high fertility rates of the inhabitants who do not have reserves to rely upon when food production is insufficient. Government policies encouraged urbanization and out-migration from the northeast and other areas to the Amazon region. They also encouraged large-scale commercial agricultural enterprises. As a result, large landowners bought land for cattle ranching. They tend to displace sharecroppers during drought periods in order to have sufficient water for the animals.

The migrants go everywhere in Brazil, but about 70 percent have moved to the southeastern part of the country. That pattern is likely to continue or grow with the close of the Amazonian frontier and the restrictions that are being placed on mining and other activities. The expectation is that there will be a flow of people from the Amazonian cities to those in the southeast because the former are unable to support their populations.

Gonzague Pillet provided a case study of the "carrying capacity" of Switzerland, which he defined as the maximum population that can be supported indefinitely in a given environment. He has been developing a model for analyzing the interchange between environmental factors, economic factors and migration in order to understand the population size that nations can carry. His analysis underscores that developed countries have often maintained their high economic standards of living through the importation of natural resources and labor from the developing countries. Switzerland by his analysis uses 3.5 times as many resources as it produces and must thus import energy and other goods. Mr. Pillet argued that migration and refugee policy should become part of the environmental debate given this relationship between population size, utilization of resources and economic development. 
Comments on the Pillet case study were offered by Hans-Peter Muller and Verena Tobler Muller. They noted that ecological sustainability is only one aspect of the carrying capacity of nations. Cultural integration, social cohesion and collective learning capacity are equally important in defining the carrying-capacity of a nation. They further argued that refugee policies, particularly in developed countries, contribute to a weakening of social cohesion and reinforcement of cultural disparities by providing for a higher standard of living and greater attention to individual rights than is attainable in countries of origin. For many migrants the system creates dependence and reduces the potential for repatriation. Refugee and migration policy, they argued, must distinguish between preventive measures to address the causes of the movements and programs to treat the symptoms of these causes.

Environmental migration in India was the topic of a case study presented by K.V. Raju. Environmental migrants have been produced as a result of natural disasters such as floods, cyclones and earthquakes; human-caused disasters such as deforestation, wasteland, waterlogging and salinity; human-made projects such as dams, coal and other mines, industries, thermal plants, power projects, forest and wildlife reserves; and political and economic disruptions in Kashmir, Punjab and other regions. In addition, people have entered India because of economic and natural disasters in Bangladesh and Nepal; the civil conflict in Sri Lanka; and the war in Afghanistan. Some of these are also environmental issues because of the huge population pressure on the land.

In his remarks, Raju focused primarily on displacements caused by development projects. Irrigation projects alone have displaced about 6.5 million people in India. A total of about 20 million have been uprooted by all of the development projects. Some of these migrants were directly displaced by a dam or other project; others moved as common land and water were reduced as a result of these projects. These movements are particularly serious because there are no policies for reducing the impact of relocation. Land is not available for rehabilitation or compensation when people are relocated. The absence of relocation policies creates secondary migration, particularly to cities. Currently, no framework exists for negotiations between the government and the uprooted regarding ways to deal with the causes and consequences of this displacement. It is argued that the projects are in the public interest, but there is no way to measure whether the degree of displacement caused by the projects is in fact in the public interest.

Bryan Spooner spoke about environmental migration in the Horn of Africa. Most of the issues discussed so far also exist in the Horn of Africa, he noted. In addition, the state of collapse of the political system means that programmatic responses cannot be effectively implemented.

Migration in the context of the Horn is often a solution not a problem. People are resourceful in coping with fragile ecosystems by moving temporarily to other locations. Part of the survival strategies is flexibility in adapting to changing environmental pressures. Drought is cyclical; during dry cycles movement into riverine areas makes sense. Such behavior requires the cooperation of the receiving locations, however. Some host locations see migration as beneficial to them. Where neighboring areas are unwilling to allow those affected by a drought cycle to relocate, it may be difficult to use traditional coping mechanisms. The conflicts throughout the Horn are compounding the problem. The normal 
arrangements for coping with drought are being undermined by the prevalence of violence and overpopulation within the region.

Mr. Spooner underscored the need to involve the migrants themselves in identifying the appropriate responses to their movements. Otherwise, the international aid system will further undermine the traditional coping mechanisms. An aim of international assistance should be restoration to the people involved of their own capacity to manage resources.

Arthur Westing provided further perspectives on the relationship between the environment, migration and conflict. He noted that environmental damage is a collateral effect of warfare. In some cases, the environmental degradation is unintentional but in others it is a hostile act. "Unleashing the forces of nature" can be an effective military strategy. Several bombs can destroy a dam which in turn destroys the habitability of an entire region. Migration as a result of such environmental warfare takes two forms: temporary movements to escape harm's way and permanent movements because of the long-term destruction of the habitat.

In the ensuing roundtable discussion of the case study findings, one participant took issue with the concept of carrying capacity. The case study on Switzerland assumed a finite area that could be self-sustaining. Very few countries, however, could ever be totally selfsustaining in their generation and use of resources. The interdependence of the world economy needs to be factored into the analysis. Moreover, according to another participant, the concept of carrying capacity can too easily lead to anti-foreign, anti-migratory policies aimed against those who may have little choice about moving.

Others agreed, noting that a certain amount of migration is beneficial and, as stated in the Horn of Africa case study, may be part of a survival strategy that is accepted by both the migrants and the receiving areas.

Several participants commented on the relationship between development projects and environmental migration. The World Bank has developed guidelines to reduce forced displacements and to encourage, where displacements cannot be avoided, development of relocation strategies that involve the affected groups. The OECD has also adopted the Bank guidelines. Implementation of the guidelines is still a problem, however, as is monitoring their effectiveness. 


\section{ENVIRONMENTAL CONSEQUENCES OF MIGRATION}

In introducing this session, Ambassador Richard Benedick noted the various types of migration that need to be examined in relationship to their environmental impacts: south to north migration; rural to urban; internal versus external; emergency versus slow-onset movements; etc. Each type of migration has its own effects on the environment, requiring a complex array of strategies and technologies for coping with these impacts.

Josef Auer of the Program and Technical Support Service in UNHCR described the policy changes evolving within UNHCR to lessen the negative impacts on the environment of large refugee populations. UNHCR traditionally did not consider environmental impact in measuring the effectiveness of its programs. This situation is slowly changing. There is growing recognition of the need to take into account the use of environmental resources in planning assistance programs. Firewood, for example, is not a "free" resource if deforestation is the result of not providing fuel for cooking or heating. UNHCR also understands the advantage of a greater investment in water and sanitation programs, not only to help protect the environment but also to avert public health problems which result in the need for expensive curative care.

A further area of attention is the rehabilitation of already damaged areas. UNHCR has been working with the World Bank and other institutions to support programs for reforestation. Rehabilitation of the environment is particularly important in planning for repatriation. If people have left for a combination of reasons, including the destruction of the environment in their home countries because of conflict, their return will not be sustainable unless the environment is rehabilitated. If attention is not given to this issue, the returnees may become secondary migrants, seeking areas in which they can sustain themselves.

The discussion that ensued strove for a better understanding of the circumstances under which large-scale migration has a negative impact on the environment and those circumstances in which the impact is neutral or even positive. One participant posited that dispersal of refugees throughout an area would have fewer negative impacts than concentration of people in large camps. While there was general agreement with this point, another participant noted that assistance from the international community would still be needed to ensure that the refugees did not overly deplete local resources. For example, many Liberian refugees live with local families in neighboring countries; over time, however, the added population has meant that resources that would otherwise have been sufficient for these communities have been depleted.

Another participant stated that migration can be a means of balancing environmental and population imbalances. He noted that movements from high fertility areas to those with low birth rates will reduce population growth, a beneficial effect. 
Most of the representatives from western nations felt that migration has had little effect, positive or negative, on the environments of their countries. Most of the impacts on western countries appear to be social, political and economic. Several participants from developing countries concurred with this assessment, stating that the impacts on social and economic development have been substantial in the South as well. One participant referenced social conflict that has developed in parts of India that have seen environmentally-induced migration from neighboring countries.

Rapid urbanization in developing countries has created environmental problems, several participants noted. "Megacities" have been very destructive of the environment, particularly where sanitation systems have not kept pace with population growth, and transportation and industry have polluted the air and water. Such movements also hold negative impacts for the rural areas from which people move. Often, the young, most skilled and best educated choose to migrate, leaving gaps in their home communities.

Attempts to reverse the pull of these megacities and/or open up new areas for settlement have had mixed success. One participant noted that satellite cities designed to draw residents from the overcrowded megacities to newer locations often do not provide sufficient economic opportunities. Another participant stated that these smaller cities can generate jobs and other opportunities if given the chance. He noted that population growth in Mexico City has been slowed because people have been moving out of the capital to cities of 100,000-500,000 people. Another participant spoke of the benefits of government-run relocation programs in Malaysia. In contrast to spontaneous movements, the official relocation schemes provided assistance to people in relocating. 


\section{POLICY RESPONSES}

The discussion underscored that national and international organizations are ill-prepared at present to address the complicated interconnections between environmental degradation and population movements. Several areas require new approaches.

Environmental factors should be considered in efforts to obtain early warnings of humanitarian crises in the making. Early warning systems, according to one participant, are developing regarding refugee movements and, to a lesser degree, internal displacements. Famine early warning systems are already in place. A comprehensive approach is needed that would enable the international community to track the complicated migration pressures discussed at the meeting.

Further attention is also needed regarding prevention. Several participants spoke to the need for governments to help ensure that their citizenry are able to survive without being forced to move. There was general agreement that the state has the initial responsibility in this area. Where environmental problems are regional, it may be appropriate for regional organizations to become involved as well. Poor countries and regions may require outside assistance to accomplish this goal.

Bilateral and multilateral assistance should be contingent, some participants argued, on the willingness of the government to protect the environment and the rights of the individuals who are affected by environmental changes. An area requiring more attention are the circumstances, if any, in which other states should intervene to require offending countries to take preventive actions. Discussions on humanitarian intervention are now taking place, one participant noted, in forums such as the U.N. Commission on Human Rights regarding protection of internally displaced persons.

Institutions and governments that are funding development programs have a special responsibility for ensuring that these activities do not contribute to environmental degradation or the forced relocation of people without adequate safeguards. A representative of the World Bank described the guidelines developed there, noting that they had recently been adopted by the OECD as well. The guidelines state: "Involuntary population displacement should be avoided or minimized whenever feasible by exploring all viable alternative project designs.... [P]eople's needs and environmental protection must be given due weight in the decision-making process." Several participants applauded such guidelines but noted that they are too often abridged when funding decisions are being made.

Even with effective preventive action, participants agreed, some level of migration is inevitable as a result of environmental degradation. The question then is how to handle such movements. The terminology used to describe the migrants is more than semantic, participants agreed. The responsibility of states and the access of the individual migrants to 
international assistance and protection is determined by the labels that are given to them. The term "environmental refugee," several participants argued, should be used carefully to include only those who are fleeing circumstances that, absent the environmental aspects, would still render them refugees under international law. Using it more broadly, one person reasoned, confuses the issue. Another participant noted that a large number of people forced to leave their homes because of environmental degradation may indeed fit the refugee category since many of the situations encountered are precipitated by governments, often as a means of benefiting certain groups and withholding support from others. Others held that -as difficult as this might be -- the most important distinction to draw is between those forced to leave their homes and those who choose voluntarily to seek better lives elsewhere.

Distinctions need to be made between emergency movements and slow-onset situations as well. When a crisis occurs, one participant stated, the first obligation is to feed and shelter the people who have been forced from their homes. Resources that might have been used for sustainable development may be required to meet relief needs. Many natural disasters that destroy the environment are predictable, in that it can be assumed that they will occur, but it is still difficult to plan for them because one does not know when and where they will hit.

Participants suggested that planned resettlement programs rather than emergency relief programs may be a better approach to the slow-onset situations. If large areas have to be evacuated because of permanent ecological damage, it would be more humane and efficient to anticipate the movements rather than wait for a crisis to happen. They questioned, however, whether there would be sufficient financial resources and political will to implement orderly evacuation programs. Since the alternative might be emergency movements that would have harmful effects on the migrants and the receiving communities, participants felt that thinking about orderly resettlement programs should begin now.

Such planning needs to involve the active participation of the affected populations. Participants agreed that more attention needs to be given to the rights of the people whose lives are affected by environmental degradation. The people themselves may have traditional coping mechanisms that should be encouraged. Similarly, indigenous organizations must be given a stronger role in planning responses to environmental problems and the potential migration stemming from them.

A final area of public policy that requires further attention is repatriation of individuals forced to leave their home communities. Participants noted that many regional and internal conflicts that have produced refugees and environmental destruction have or may soon be resolved. The resolution of these conflicts should allow refugees and internally displaced persons to return to their homes. Where there has been massive damage to the environment or where landmines have been planted throughout the country, it will be difficult for people to resume their normal lives without reclamation of the lands that have been rendered uninhabitable. The financial costs for rehabilitation of agricultural and other lands will be very high. New technologies for accomplishing large-scale reclamation are also needed as is training for the staff of the relief and development organizations that will be involved in repatriation efforts. 


\section{CONCLUSIONS}

The UNCED process provides an opportunity to place the issue of the environment and migration on the international agenda, the meeting participants concluded. Referencing $\mathrm{Mr}$. Desai's point that UNCED is the beginning not the end of a process, the meeting detailed an agenda of activities that should be pursued in the coming months and years.

The issues requiring attention include:

- addressing the causes of environmental migration, particularly regarding the dynamics among root causes, such as underdevelopment, overpopulation and civil conflict, and proximate causes, such as drought, destruction of agricultural lands, mining of areas, etc.;

- understanding the characteristics and needs of those most likely to be forced from their homes by environmental degradation;

- developing a framework for assigning responsibilities within and among states, regional organizations and international agencies;

- determining the rights of those who are forced to leave their homes because of environmental degradation, particularly the status to be accorded those who cross an international border;

- developing strategies for those whose displacement by environmental degradation cannot be averted to help them relocate and adapt to their new home;

- developing strategies for the rehabilitation of the environment where it may be possible for environmental migrants to return;

- increasing understanding of traditional coping mechanisms for dealing with changes in the environment in order to build responses, to the degree possible and constructive, around the preferences of those who are most affected by the movements (the migrants themselves and the communities which they may enter); and

- developing more effective strategies for assisting refugees and other migrants so as to minimize negative impacts on the environment and reduce long-term dependence on assistance. 
Improvements are needed in the information available for use in formulating more effective preventive actions as well as policy and program responses to emerging population movements. The group called for research on the issues listed above and for the formulation of options to be considered by policy makers and operational agencies.

Progress in identifying new strategies will require new coalitions that include environmental groups, humanitarian/relief organizations, migration groups, development agencies, population groups and human rights organizations. Several participants underscored the importance of the displaced themselves being a part of these efforts. Participants also spoke of the need to promote discussions among operational agencies as to the best on-the-ground strategies for tackling these difficult issues. Finally, participants recognized that resources will be needed if effective preventive actions are to be taken and if the needs of environmental migrants and their receiving communities are to be met. 


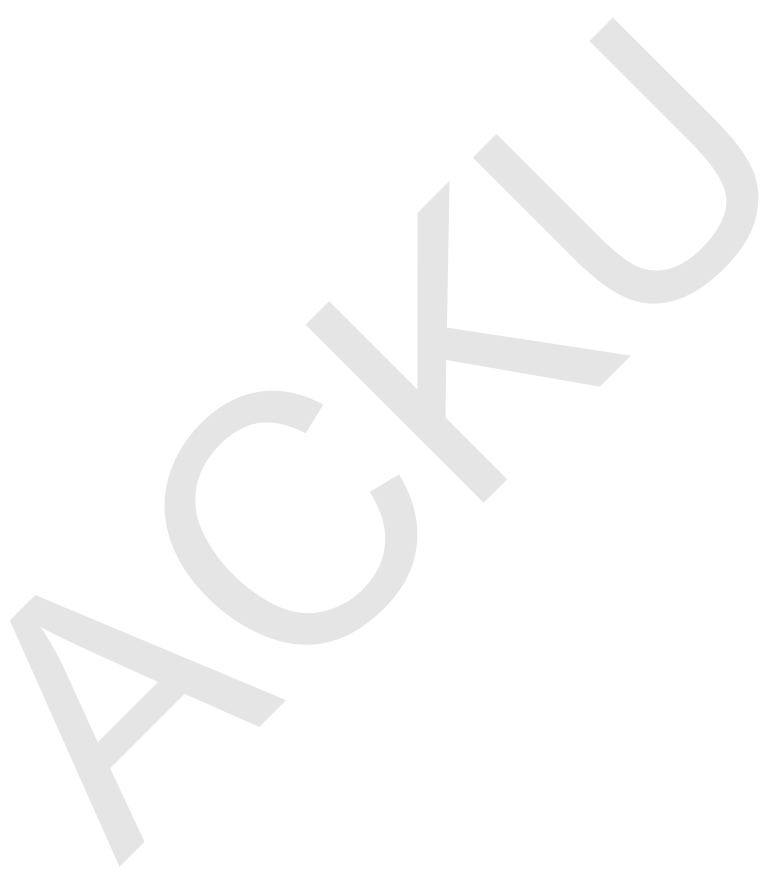




\section{LIST OF ATTENDEES}

\section{Migration and the Environment}

Nyon, Switzerland -- January 19-21, 1992

Mr. Josef Auer

Programme and Technical Support

U.N. High Commissioner for Refugees

Professor Tunku Shamsul Bahrin

Faculty of Arts and Sciences

University of Malaya

Ms. Julie Bail

Counsellor Immigration

Australian Embassy

Mr. Richard Benedick

Ambassador, Senior Fellow

World Wildlife Fund

Ms. Nina Birkeland

Research Associate

International Environmental

Conflict Resolution

Department of Geography

Mr. Delmar Blasco

Executive Director

Int'1 Council of Voluntary Agencies

Mr. Jan Borgen

Policy and Legal Affairs

Norwegian Refugee Council

Mr. J. Burger

U.N. Centre for Human Rights

Dr. Robert S. Chen

Assistant Professor (Research)

Alan Shawn Feinstein World Hunger

Program

Brown University
Mr. Jacques Cuenod

Senior Advisor

Refugee Policy Group

Mr. Nitin Desai

Deputy Secretary-General

UN Conference on Environment and

Development

Mr. Timour Dmitrichev

Deputy Director

Office for Research and Collection of

Information

United Nations

Dr. Mohanddan Farooque

Research Fellow

Bangladesh Centre for Advanced Studies

Mr. Werner Fornos

President

Population Institute

Mr. Thomas Fox

Director

Center for International Development and Environment

World Resources Institute

Mr. Dennis Gallagher

Executive Director

Refugee Policy Group

Mr. Bimal Ghosh

Senior Consultant to the

International Organization for

Migration

Center for European Political and

Economic Analysis

Migration and Refugee Program 
Mr. Peter Harder

Associate Deputy Minister

Employment and Immigration

Mr. Sanjoy Hazarika

Correspondent

New York Times

New Delhi Bureau

Mr. Allan Jury

Counsellor for Refugee and

Migration Affairs

U.S. Mission in Geneva

Dr. Palitha Kohona

First Political Secretary

Australian Permanent Mission

Dr. Mary M. Kritz

Associate Director

Population and Development Program

Cornell University

Mr. John Lange

U.S. Mission in Geneva

Mr. Reinhard Lohrmann

Chief

Division of Research and Forum Activities

International Organization for Migration

Dr. Urs Luterbacher

Graduate Institute of International

Studies

Consortium for an International

Earth Science Information Network

Professor Wolfgang Marschall

Director of the Institute of Ethnology

Berne University

Dr. Susan Forbes Martin

Senior Associate

Refugee Policy Group
Ms. Zoraida Mesa

Head of the Liaison Office

Geneva

World Food Programme

Mr. Klaus von Mitslaff

Senior Management Advisor

Policy Unit

German Agency for Technical

Cooperation (GTZ)

Mr. Luc J. A. Mougeot

Environment Department

World Bank

Professor Hans-Peter Muller

Ethnologisches Seminar

University of Zurich

Ms. Verena Tobler Muller

Soziologin

University of Zurich

Dr. Shafika Nasser

Professor of Community Medicine

University of Cairo

Mr. Desta Negousse

Counsellor

Permanent Delegation of the

Organization of African Unity

Mr. Michael Palmer

Independent Consultant

Dr. Gonzague Pillet

President

Ecosys Ltd.

Mr. James Purcell

Director-General

International Organization for Migration

Professor Carol De Raedt

Cordiera Studies Center

University of the Philippines 
Dr. K.V. Raju

Social Scientist

Water and Power Consultancy Services Ltd.

Mr. Thomas Sanders

Independent Consultant

Ms. Marie-Angelique Savane

Special Advisor to the

U.N. High Commissioner for Refugees

Mr. Peter Schatzer

Chief, External Affairs

International Organization

for Migration

Dr. Walter Schiesser

Editor

Neue Zurcher Zeitung

Ms. Michelle Schwartz

Legal Director

Environmental Refugee Project

Natural Heritage Institute

Mr. Moussa Seck

Agronomist

Future Systems Research Department

ENDA

Mr. Bryan Spooner

Independent Consultant

Dr. Astri Suhrke

Director, Human Rights

Program

Chr. Michelsen Institute

Mr. Patrick A. Taran

Secretary for Migration

World Council of Churches

Mr. Michael Vlassoff

Senior Technical Officer

Technical and Evaluation Division

U.N. Population Fund
Ambassador Rudolf Weiersmuller

Coordinator for International Refugee Policy

Swiss Federal Department of Foreign Affairs

Mr. John Weiss

U.S. Mission in Geneva

Mr. K. Weisshaupt

Office of the Coordinator for International

Refugee Policy

Swiss Federal Department of Foreign Affairs

Dr. Arthur H. Westing

Westing Associates in Environment, Security, \& Education

Mr. Jonas Widgren

Coordinator for Intergovernmental

Consultations on Asylum, Refugee

\& Migration Policies in Europe,

North America and Australia

Ms. Ellen Wiegandt

Consortium for an International

Earth Science Information Network

Graduate Institute of International

Mr. James N. Ypsilantis

Senior Population Analyst

IUCN (World Conservation Union) 
